\title{
Bronze production in the Iron Age of the Iberian Peninsula: The case of $E l$ Castru, Vigaña (Asturias, NW Spain)
}

\author{
Carlotta Farci a,*, Marcos Martinón-Torres a , David González Álvarez b,c \\ a Institute of Archaeology, UCL 31-34 Gordon Square, London WC1H OPY, UK \\ b Instituto de Ciencias del Patrimonio, CSIC, Spain \\ c Department of Archaeology, Durham University, UK
}

\section{A R T I C L E I N F O}

\section{Article history:}

Received 1 June 2016

Received in revised form 29 November 2016

Accepted 8 December 2016

Available online $\mathrm{xxxx}$

\section{Keywords:}

Spain

Late Iron Age

Bronze technology

Cementation

Co-smelting

SEM-EDS

Crucibles

\begin{abstract}
A B S T R A C T
Bronze production during the Iron Age of the Iberian Peninsula is characterised by the use of a relatively simple technology, based on crucible-furnaces. In an area rich in mineral resources, bronze was produced on a small scale and within settlements, to be used for ritual, ornamental and functional objects.

Here we present an analytical study of slagged crucibles, small slag nodules and casting spillage from the Iron Age hillfort of El Castru, in Vigaña (Asturias, NW Iberia), with a particular focus on the technology of bronze production. The study sought to contribute to our understanding of Pre-Roman metallurgical activities in the region, as a case in point to discuss broader prehistoric traditions of bronze-making.

The results show that the technology and scale of bronze production at this hillfort are coherent with the pattern described for much of prehistoric metallurgy in Iberia, with the -direct production of copper alloys by cementation and co-smelting of mineral ores. The results also illustrate some of the challenges encountered when attempting to identify metallurgical processes through the analyses of crucible residues, and propose some criteria to facilitate future studies.
\end{abstract}

Crown Copyright $@ 2016$ Published by Elsevier Ltd. All rights reserved.

\section{Introduction}

The Iberian Peninsula is characterised by the existence, and persistence well into the Iron Age, of a metallurgical technology based on the use of crucibles for the extraction of metals from their mineral ores (Rovira, 2006), in stark contrast with the furnace-based metallurgy that predominates in the later prehistory of the rest of Europe and the Near East. The present study is a contribution to further characterise the geographic and diachronic variability of this tradition. Non-ferrous metallurgical debris recovered in the Spanish Iron Age hillfort known as El Castru in Vigaña (Belmonte de Miranda, Asturias), were subjected to technical characterisation by means of optical microscopy and SEMEDS analysis. A major focus of the research is the technology employed for the production of copper alloys. Focusing primarily on slagged crucibles, as well as small slag and metal pieces, we sought to characterise bronze-making technology at the site, and to contextualise our results more broadly in regional and archaeometallurgical studies concerning prehistoric bronze production. Using El Castru as a case in point, we also discuss the challenges associated to the identification of different

\footnotetext{
* Corresponding author.

E-mail addresses: farcicarlotta@hotmail.com (C. Farci),m.martinon-torres@ucl.ac.uk (M. Martinón-Torres), david.gonzalez-alvarez@incipit.csic.es (D.G. Álvarez).
}

bronze-making processes based on the analysis of crucibles, and provide some pointers for future research.

\section{Excavations at El Castru in Vigaña}

The Iron Age of NW Iberia (9th-1st century BC) is characterised by the predominance of monumentalised settlements known as castros (hillforts), which evidence the full sedentarisation of local communities in mountainous areas during this period. This site type gave rise to the culture-historical denomination of the Castro Culture as a rather uniform entity (i.e. Maluquer de Motes, 1975; Maya González, 1983). More recent research has revealed greater sociocultural diversity within the Castro Culture label than initially assumed (Marín Suárez, 2011a), leading to more regionalised approaches to the temporal and spatial variability of this phenomenon (González Ruibal, 2006, 2011; Marín Suárez, 2011b; Parcero Oubiña, 2003; Sastre, 2011).

In general terms, these groups are characterised by a production system governed by family groups. The control and exploitation of the territory was in the hands of the communities who lived within individual settlements providing goods for themselves; thus social communities were connected to a landscape in which they could be largely self-sufficient (Sastre, 2011). Iron Age material culture "has often been depicted as representing continuity" (González García et al., 2011). In the realm of copper metallurgy, this conservatism may be in part due to the 
geological characteristics of the territory, which offered extensive mineral resources to the local communities (Rovira, 2002), who took advantage of the cooper resources at least since the second half of the Third Millennium cal BC (de Blas Cortina and Suárez Fernández, 2010). Easy access to raw materials and a low cost/benefits ratio provided little incentive to innovate or optimise production methods.

The hillfort of El Castru is located near to the small village of Vigaña (Asturias, Spain). Among the diversity of Iron Age communities in NW Iberia, this small site is thought to have been inhabited by a small group of a few dozens of people, which would fit in what González Ruibal (2011) has defined as "deep rural communities" model. These groups had a sort of heterarchical model of social organisation, and the local community in every hillfort would play a central role in the political, productive and identitarian structures (González Álvarez, 2016; Marín Suárez, 2011b). El Castru was excavated during two campaigns, in 2012 and 2013, by archaeologists of the University of León and the University Complutense of Madrid. The hillfort is located on the top of a small limestone outcrop over the valley of the Pigüeña River (Fig. 1). Excavations concentrated on two distinct areas of the hillfort, covering a total extension of $72 \mathrm{~m}^{2}$. A first $3 \times 4 \mathrm{~m}$ trench was excavated in one of the terraces on the western hillside, outside the walled perimeter of the site. A second excavation took place at the top of the hill, where archaeologists aimed to find dwellings and evidence of domestic activities. The excavation of a $6 \times 10 \mathrm{~m}$ trench revealed the presence of domestic units and structures associated to metallurgical operations (Figs. 2 and 3) (González Álvarez, 2016), which will be explored in detail in this paper.

The stratigraphic sequence in El Castru was organised in six phases, the earliest of which dates to the Early Iron Age. The levels with metallurgical remains were dated to the Late Iron Age by means of ceramic typology and radiocarbon dating. Two radiocarbon dates were obtained, which yielded 2-sigma calibrated ranges of 359-108 cal BC (DSH5058, charcoal) and 403-120 cal BC (Fi2985, bone), respectively (Fernández Mier and González Álvarez, 2013; González Álvarez, 2016).

The identification of pits with a fill rich in clay and charcoal fragments, along with crucibles, a few slag fragments and bronze scraps indicates that metallurgical activities were carried out within the settlement. At least two associated round structures (Cu-1 and $\mathrm{Cu}-2$ in Fig. 2), made of yellow clay tempered with pebbles and occasional bone fragments, showed evidence of intense heat impact. The two structures belong to the same phase and were tentatively interpreted as some heating installation associated to metalwork. The majority of the material analysed in this study comes from the installation labelled Cu-1 (Fig. 2). At the centre of the structure, underneath the clay lining, the excavation revealed a platform made of medium-sized stones, seemingly intentionally placed (Fig. 3). This metallurgical area would be later dismantled by the construction of two roundhouses during the phase 4 of the archaeological sequence. In fact, the perimeter ditch for the foundation of hut C-1 partially affected the conservation of the metallurgical structure $\mathrm{Cu}-1$.

The characteristics of the pits found next to the enclosing walls, as well as the other metallurgical materials recovered, resemble those found in Late Iron Age levels in the nearby hillforts of La Campa Torres (Maya González and Cuesta Toribio, 2001), Llagú (Berrocal-Rangel et al., 2002) and El Chao Samartín (Villa Valdés, 2005), also in Asturias (see Fig. 1).

An interesting characteristic observed in Asturian castros, and which seems typical of the Iron Age in NW Iberia, is that the metallurgy of copper and iron was carried out in the same workshop and, possibly, by the same artisans (Fernández-Posse et al., 1993; Rovira and Gómez Ramos, 2001; Fanjul Peraza and Marín Suárez, 2006). In El Castru, fragments of iron objects were recovered alongside the crucible remains (González Álvarez, 2016). It is not known however, whether iron was produced at the site or brought from other castros. Iron appears in NW Iberian hillforts during the first half of the first millennium $B C$, in a context characterised by the continuity of metallurgical techniques employed for the production of bronze (Camino Mayor and Villa Valdés, 2014). Ferrous metallurgical remains and possible iron smelting furnaces have been found in many Asturian castros, such as La Campa Torres (Rovira and Gómez Ramos, 2001), Llagú (Berrocal-Rangel et al., 2002) and San Chuis (Jordá Pardo et al., 2011), and other sites in the broader region such as La Corona de Corporales and El Castrelín de Paluezas in León (Fernández-Posse et al., 1993) or Santa Comba in Galicia (González Fernández, 2002). The evidence from these sites suggests that different technologies and scales of productions may have coexisted, possibly also within the same settlements.

With the introduction of iron, weapons and tools started to be produced with the "new" metal, while it seems that bronze acquired a new importance in the manufacture of jewellery, adornments, etc. This is confirmed both by the new type of objects introduced at the end of the Bronze Age and beginning of the Iron Age (fibulae, sheets,

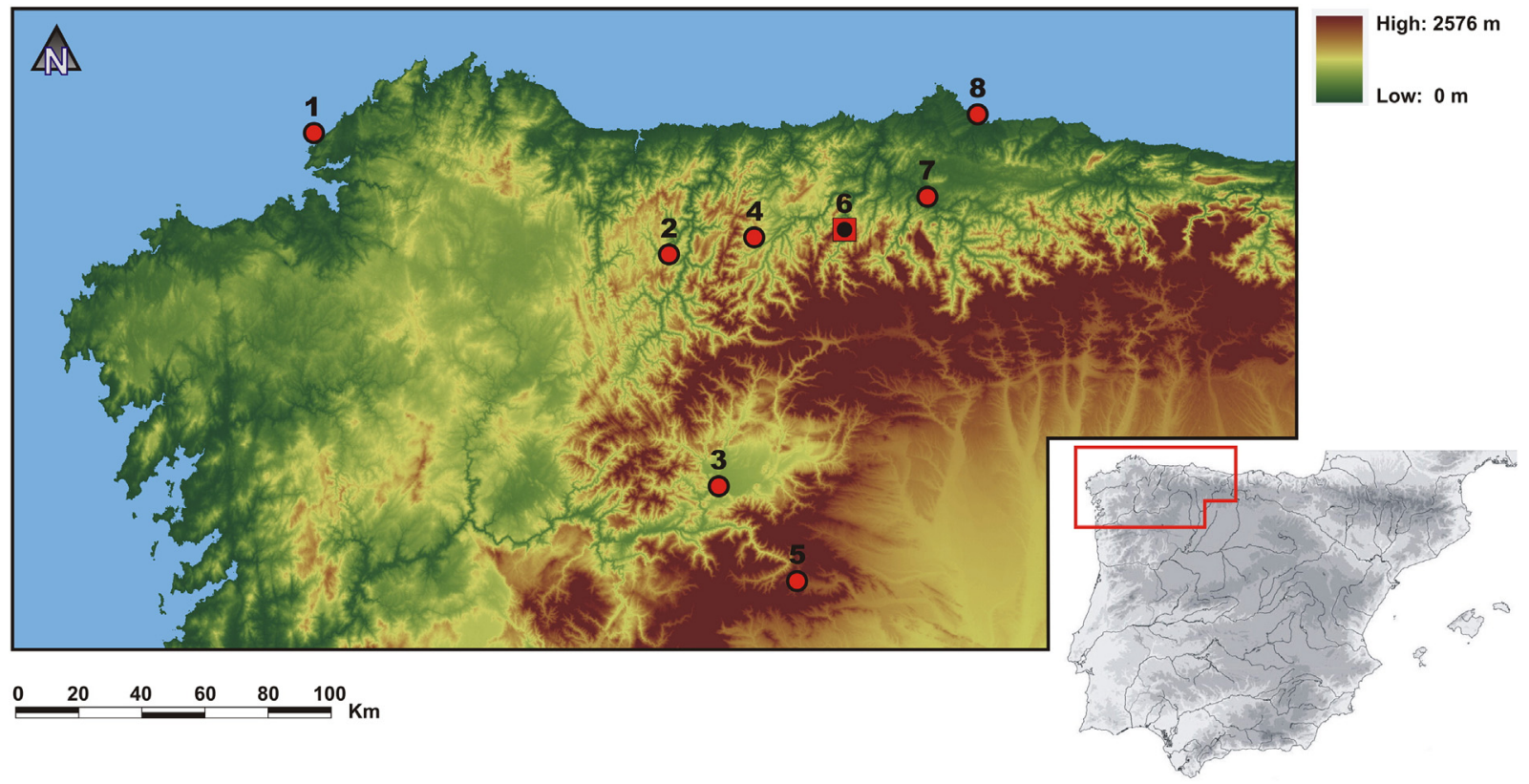

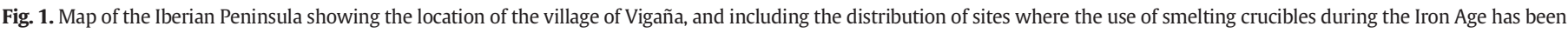

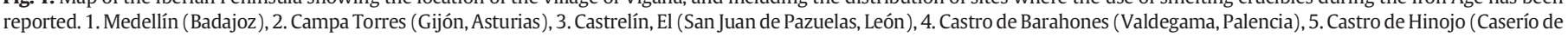

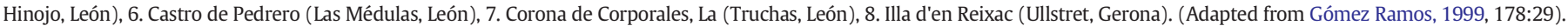




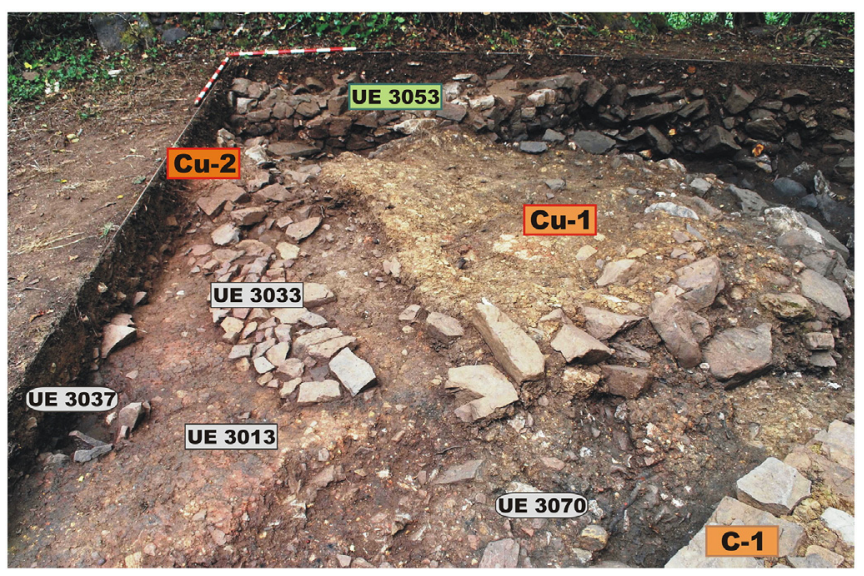

Fig. 2. Metallurgical structure excavated at Vigaña. The majority of the material analysed in this study comes from $\mathrm{Cu}-1$ (photos by DGA).

jewellery etc.), and by the relatively small dimensions and capacity of the crucibles used in their production (Rovira and Gómez Ramos, 2001: 375).

\section{Materials and methods}

Among the material found at the site indicating metallurgical activities, there were crucible sherds - mostly rims - small rounded slag nodules and metallic droplets probably representing casting spillage. Twenty-nine crucibles and over 300 fragments between slag nodules and metallic droplets were recovered from excavation. Our analysis involved first a visual assessment and documentation of the entire assemblage, focusing on the overall characterisation of the crucible fabrics, wall thickness, diameters, and appearance of the residues. This was supplemented by screening analyses by portable X-ray fluorescence spectrometry (pXRF). Subsequently, a number of crucibles were selected for more detailed investigation. We particularly targeted those with thicker and better preserved metallurgical residues adhering to the inner surfaces, and whose position within the crucible could be verified. These were mounted as polished cross-sections following established procedures, and analysed under a reflected light optical microscope (Leica DM4500 P LED) and a scanning electron microscope with an energy dispersive spectrometer (SEM-EDS). All the SEM images included in this paper are from the backscattered electron detector (BSE). The SEM employed was a Philips XL30 with an Oxford Instruments EDS, operating at $20 \mathrm{kV}$ and at a working distance of $10 \mathrm{~mm}$, with acquisition times of $100 \mathrm{~s}$, and calibrated with a pure cobalt standard every $30 \mathrm{~min}$. All chemical compositions are reported in percentage by weight, with compounds calculated by stoichiometry where appropriate. Quantification limits for this instrument are around $0.2 \%$ for most elements, and we therefore chose not to report values under this threshold, except when they are averages of several measurements and some of them were well above this limit.

\section{The crucibles}

Most of the recognisable crucible fragments recovered in Vigaña are rim sherds. A few crucibles that preserved the entire profile were also identified, which allowed for some consideration on their shapes and types. The majority of the vessels are hand-shaped using fine white clay, containing relatively abundant quartz grains and some feldspars, typically of small size $(\leq 500 \mu \mathrm{m}$ diameter). Some of them however show dark pastes and their mineral inclusions are larger (Fig. 4).

Their walls are generally $1-2 \mathrm{~cm}$ thick; the base is thicker and flat. Some of them were manufactured in shallow open shapes with straight, opening walls (Fig. 5A), with maximum heights between 3 and $5 \mathrm{~cm}$ and estimated diameters between 5 and $10 \mathrm{~cm}$, corresponding to volumes around 80 to $100 \mathrm{~cm}^{3}$. Gómez Ramos (1999: 37) states that almost $900 \mathrm{~g}$ of copper could be melted in crucibles of this kind, but the actual figure is likely considerably smaller, as the volume would have to accommodate charcoal and, often, minerals. In fact, 'tide marks' on the inner surface
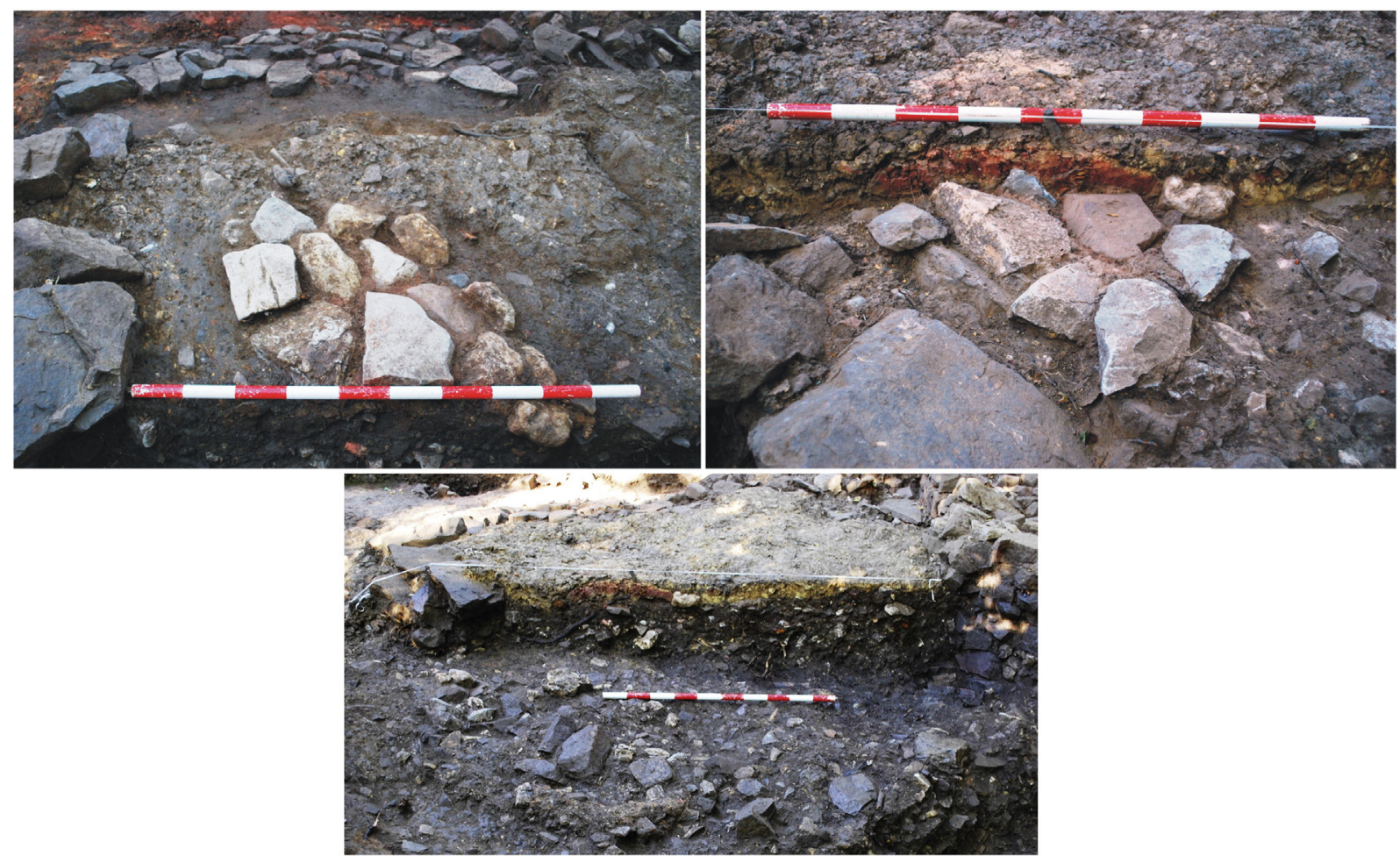

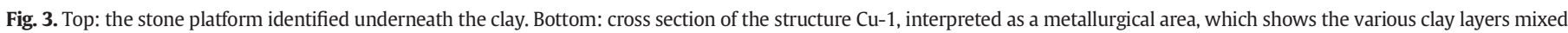
with stones and charcoal (photos by DGA). 
a

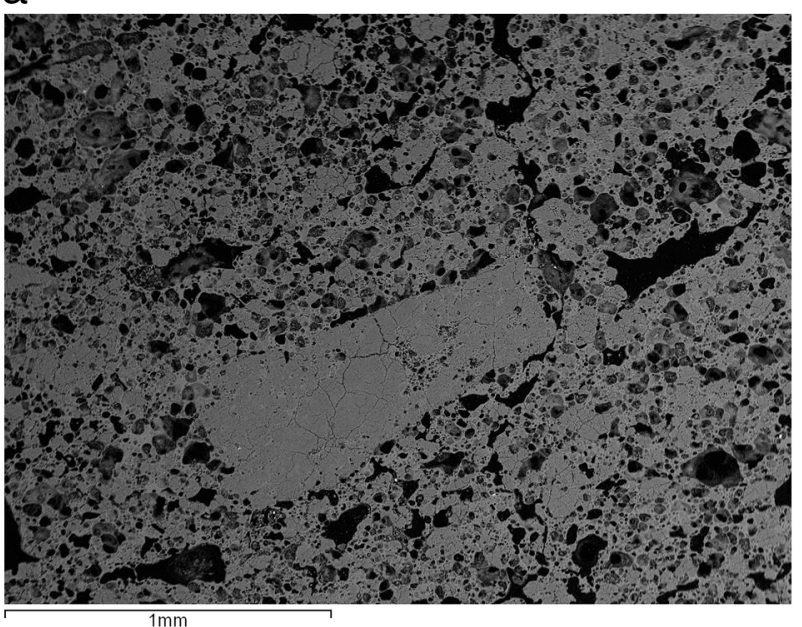

b

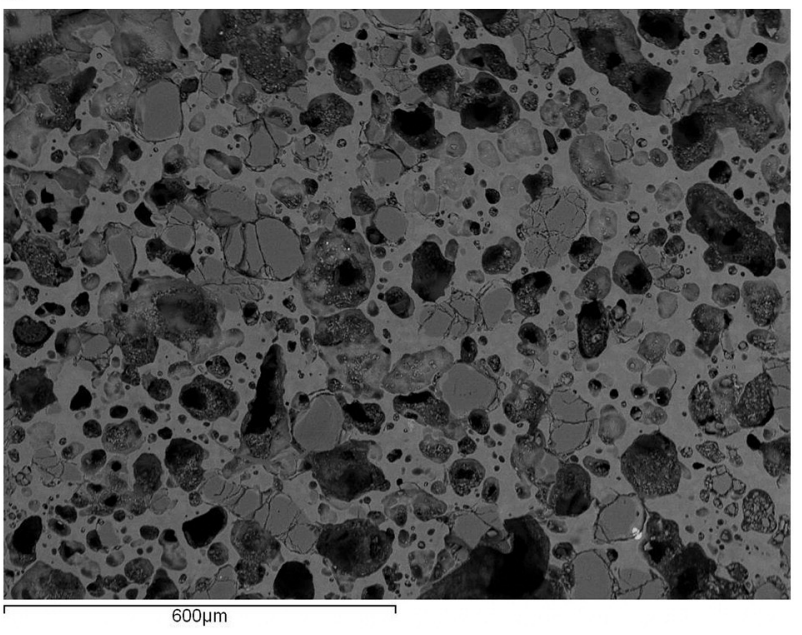

Fig. 4. BSE images of the ceramic fabric of crucibles 405 (a) and 420 (b) showing predominantly small mineral inclusions, often shattered by thermal stress, and abundant round vitrification voids.

of the sherds left by slag or dross floating on the molten metal are often 1 $2 \mathrm{~cm}$ below the rim. Other crucibles have more vertical walls and are cupshaped (Fig. 5B), with even smaller volumes. These dimensions are therefore consistent with a relatively small scale of production.

A common feature is the presence of black, slagged inner surfaces, often containing bloating pores, green and/or red copper-rich stains and metallic prills.

These slag layers are often thicker towards the rim, clearly indicating that they formed on top of molten metal (Fig. 6A). The vitrified layer often extends to the top of the rim and the uppermost part of the outer surface, but not beyond. Thermal distortion is absent or much more limited on the outer surfaces, which is consistent with the crucibles having been heated primarily from above, with at least part of the fuel contained in the vessel itself and mixed with the other reagents. In their study of comparable crucibles from La Campa Torres, Rovira and Gómez Ramos (2001) propose that crucibles would have been surrounded and covered by burning charcoal in crucible smelting operations; a similar arrangement is plausible for El Castru.

The heating gradient was also ascertained during microanalyses, which systematically showed bloated inner surfaces and much less vitrified pastes towards the exterior, except for the superficial ash glaze on the outer part of the rim. Excluding the surfaces, the core of the ceramic fabrics generally shows initial vitrification with development of fine to medium bloating pores; smaller quartz grains often appear thermally shattered, and feldspars beginning to dissolve in the surrounding matrix (Fig. 4A). This is all indicative of exposure to temperatures in the range of $1100-1200{ }^{\circ} \mathrm{C}$, which led to distortion of the fabrics but not to catastrophic failure. Chemical analyses of the ceramic pastes showed the use of noncalcareous clays in all cases, with moderate alumina levels and remarkably low iron oxide (average $16.4 \% \mathrm{Al}_{2} \mathrm{O}_{3}$ and $1.5 \% \mathrm{FeO}$ for the white pastes), which would explain the characteristic white colours. The two samples of darker fabrics (Fig. 12) analysed showed higher iron oxide levels ( $\geq 5.6 \%$ ), as well as slightly lower alumina and potash (Table 1 ).

The use of white clays, the shortness of the walls, and the thick flat bases, as well as the presence of different vessel morphologies, are features of the assemblage from Vigaña that are shared with other PreRoman contexts in the northern Iberian Peninsula (Gómez Ramos, 1999; Maya González and Cuesta Toribio, 2001; Berrocal-Rangel et al., 2002). At several of these sites, researchers have differentiated between 'crucible-furnaces' (hornos vasija) and 'melting crucibles' (crisoles). The first group includes generally larger vessels, thought to have been used for smelting, whereas the second type are smaller crucibles presumably used for melting/refining prior to casting. Although our sample is small and fragmentary, we could not identify such types in Vigaña or, as discussed below, any correlation between ceramic fabrics and use.

\section{The crucible slag: metallurgical processes}

Screening surface analyses with a portable XRF revealed the presence of copper, tin and lead almost invariably in the inner and outer surfaces of the crucibles, hence suggesting a link to bronze metallurgy. However, it is well known that the proportions among non-ferrous metals detected in technical ceramics can be misleading due to their different propensities to oxidise and react with the siliceous ceramic (Dungworth, 2000a; Kearns et al., 2010). Furthermore, chemical analyses alone can only rarely help discern whether a crucible would have been used for melting, smelting or alloying. It was only through microanalyses under the optical microscope and SEM-EDS that we could make informed inferences about the likely uses of the various vessels. In particular, as in previous studies elsewhere, we tried to discern among four possible scenarios: a) remelting of scrap bronze, b) alloying of copper or scrap bronze with additional metallic tin, c) cementation of cassiterite with metallic copper, and d) co-smelting of mixed copper and tin minerals (cf. Cooke and Nielsen, 1978; Dungworth, 2000b; Crew and Rehren, 2002; Pigott et al., 2003; Renzi et al., 2007; Rovira, 2007; Rovira et al., 2009; Figueiredo et al., 2010; Murillo-Barroso et al., 2010; Eliyahu-Behar et al., 2012; Valério et al., 2013; Rademakers et al., 2013).

As discussed in the following sections, we focused on a series of traits in the slag that we took as informative of the various processes: a) presence and composition of metallic prills; b) presence of residual mineral grains, or pseudomorphs of these; c) morphology, composition and distribution of tin oxide crystals; and d) overall composition and microstructure of the slag layer. Average slag compositions are reported in Table 2, and a summary of our observations is in Table 3.

Based on these, we tentatively classified our samples in three functional groups, which are discussed in turn.

\subsection{Bronze making}

Some of the crucibles show clear evidence of the direct production of the alloy bronze, most likely by the cementation of cassiterite with metallic copper - although we cannot discard completely the possibility of co-smelting. In two of the crucibles, the composition of the metallic globules is quite variable but always including some with exceptionally high tin levels: tin levels range between 6 and 26\% in globules in crucible 417 (Fig. 6), while this range goes from 0 to 30\% in sample 424 (Fig. 7). This is strong evidence that alloying was taking place through the addition of a fresh source of tin, as no bronzes with such high tin contents are known for the Iberian Iron Age (but see de la Peña Santos, 1988 for an exception). In addition, nodular grains of cassiterite are found in 
A
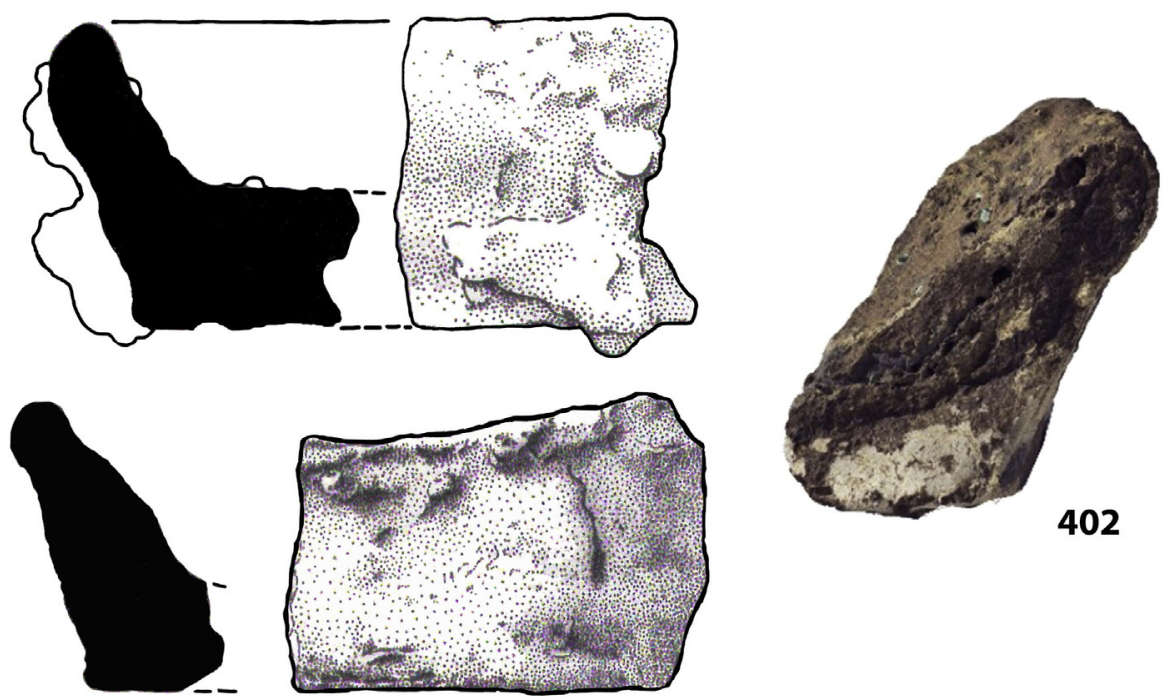

B
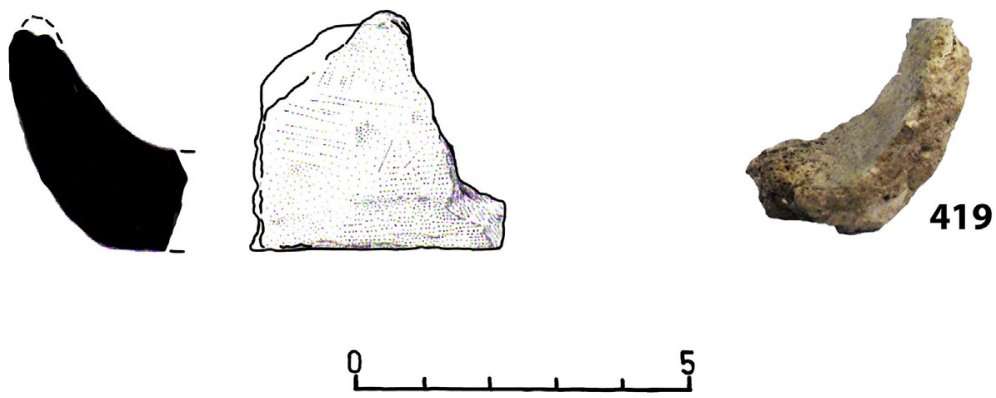

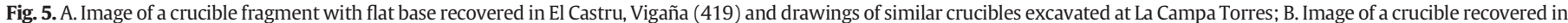

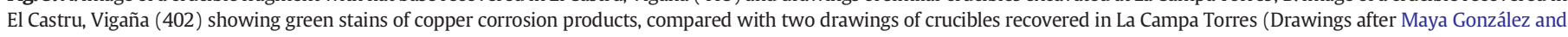
Cuesta Toribio, 2001: 246). (For interpretation of the references to colour in this figure legend, the reader is referred to the web version of this article.)

both, especially in 417, where these often appear clustered in what is likely to represent pseudomorphs of the tin ore grains added to the charge (Fig. 6B). The same features are noticeable in a small $(\sim 1 \mathrm{~cm})$ black lump of slag, found by itself, but probably originating from a similar process carried out in a crucible (sample 730, Fig. 8). Here, metallic bronze prills are found with tin levels reaching up to $56 \%$.

Some euhedral, rhomboidal and/or acicular $\mathrm{SnO}_{2}$ crystals are found in both samples of 417 and 730, coexisting with the cassiterite pseudomorphs (Figs. 6B and 8A). Those may well derive from partial oxidation of the tin after it had been reduced (see e.g. similar crystals in slag from a co-smelting experiment in Rovira et al., 2009), although it is also possible that cementation was carried out with low-tin scrap bronze rather than pure copper. Their presence simply bears witness to the variable redox conditions within the same crucible and process - it is the residual cassiterite pseudomorphs that are diagnostic here. Also indicative of the variable redox environment is the abundance of both wüstite $(\mathrm{FeO})$ and magnetite $\left(\mathrm{Fe}_{3} \mathrm{O}_{4}\right)$ in different areas of samples 424 and 730 (Figs. $7 \mathrm{~B}$ and $8 \mathrm{C})$.

In sample 424, a stringer of slag appears to have seeped into the ceramic body through a crack, and this is now dominated by fayalite, with occasional spinels and bronze prills bearing up to $19 \%$ Sn and 4\% Fe (Fig. 7C and D).
The presence of cuprite in some of the slag layers is difficult to interpret conclusively. When it occurs as dendrites, it can be safely concluded that it crystallised out of a melt. When detected as globules, however, it is harder to determine whether these are remainders of partly reacted copper ores that were not reduced to metal, or the products of post-depositional oxidation of metal prills. This is the case in samples 424 and 730 . In sample 730, cuprite globules co-occur with iron-bearing high tin bronze prills and newly formed, euhedral $\mathrm{SnO}_{2}$ crystals, sometimes in close proximity (Fig. 8). This suggests that the oxidation of copper is post-depositional: given that both $\mathrm{SnO}_{2}$ and $\mathrm{Fe}_{3} \mathrm{O}_{4}$ have higher free energies of formation than $\mathrm{Cu}_{2} \mathrm{O}$, one would expect all the tin and iron in the bronze to have oxidised during high temperature processing before the copper began to oxidise (or, alternatively, if all of these elements entered the crucible as oxides, all $\mathrm{SnO}_{2}$ would have been reduced before the formation of any metallic copper). In sample 424, however, there are no obvious signs of newly formed cassiterite that would point to an oxidising environment, hence we cannot rule out the possibility that some copper entered the crucible in oxide form. We should also note that in each of two samples ( 405 and 429, see Figs. 9 and 10) we found a relatively large, cubic grain of cuprite (Figs. 9B and $10 \mathrm{E})$. However, it is apparent in both cases that the grain grew in a 

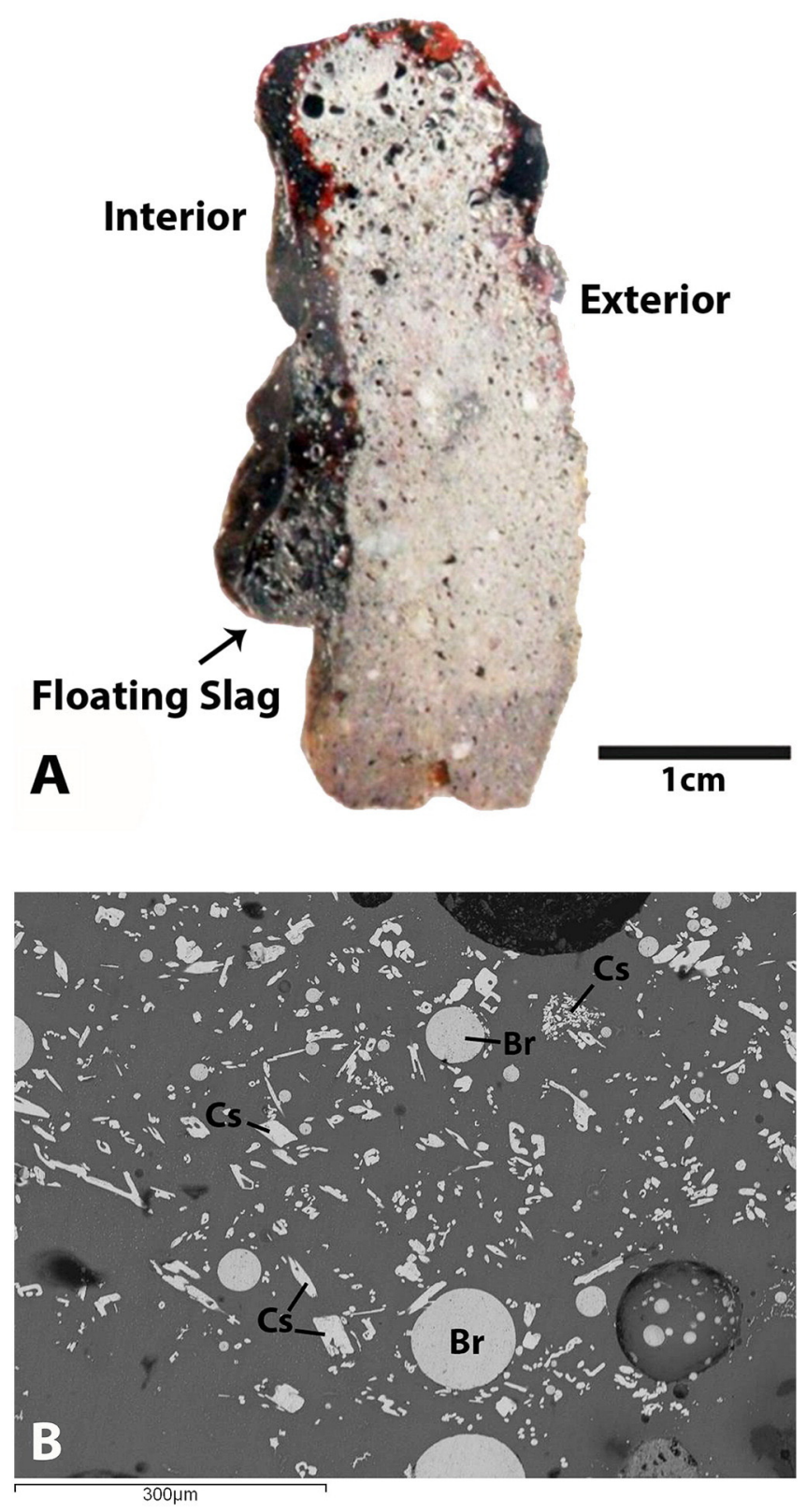

Fig. 6. Crucible 417. A. Polished section showing the interface between the slag that would have floated on the metal and ceramic body; B) BSE image of crucible slag showing cassiterite pseudomorphs (Cs) coexisting with euhedral $\mathrm{SnO}_{2}$ crystals and high tin bronze prills $(\mathrm{Br})$.

pore, either during solidification or post-depositionally, and hence their presence cannot be taken as indicative of the addition of copper ores to the charge.
We assume that part of the slag or inner vitrified layer of the crucibles simply derives from the high-temperature erosion of the ceramic crucible. Therefore we focus on oxides that are enriched in the slag layer compared to the ceramic itself, and which may therefore be indicative of elements entering the slag with the charge. Compared to the ceramics, the slag layers are enriched to variable extents in lime, potash, magnesia and phosphate (Table 2). While these might well derive from mineral gangue (particularly if we bear in mind the limestonerich geology), it is also possible that they may be related to the ashes of the fuel contained within the vessels, and hence they are not particularly diagnostic of the specific metallurgical process. Enrichment in oxides of copper, tin and lead are frequently found too - these resulting from the oxidation of the metal charge and its reaction with the siliceous ceramic. Rovira (2007) has argued that when the slag glass is enriched in oxides of copper (and/or lead) and these are bound in silicates, it is more likely that those entered the charge as minerals. While this argument is plausible, it is also possible that some enrichment can take place locally through the oxidation of metals near the crucible rim, and hence we can only use this proxy reliably when we have larger nodules of more 'mature' slag. Perhaps more interesting is the enrichment of these slag layers in iron oxide and manganese oxide. Iron oxide in the slag can result from oxidation/refining of ironrich copper during melting, but also from iron-rich gangue that could have been added as part of any mineral charge. However, the enrichment is so high in some samples (notably in $730, \mathrm{FeO}$ in the slag $>30 \%$ ) that it can hardly be explained based on the refining of ferruginous copper only. Instead, it seems reasonable that magnetite might have entered the charge as gangue mixed with cassiterite collected from a placer deposit, especially considering the similar density and lustre of both minerals - or perhaps as ferruginous gangue in copper ores. As for manganese, given that it requires a very high $\mathrm{CO} / \mathrm{CO}_{2}$ ratio to be reduced, this element is unlikely to be present in prehistoric metals in any significant concentrations. Its enrichment in the slag may be partly due to fuel ash too, as some wood species such as beech may be manganese-rich (Yin et al., 2011). However, the $\mathrm{MnO}: \mathrm{CaO}$ ratio is too high in some of the slag samples to be consistent with any fuel ash (exceeding 1:1 in sample 405). In sample 424, manganese enrichment is shown in the relative abundance of spinels whose composition resemble that of jacobite $\left(\mathrm{MnFe}_{2} \mathrm{O}_{4}\right)$ (Fig. 7C and D). We therefore take the enrichment in manganese oxide as a strong support to the above inference that minerals were part of the charge, which would have carried manganiferous gangue. Sample 421 additionally shows a notable slag enrichment in $\mathrm{TiO}_{2}$ that is also consistent with a similar scenario - namely, some ilmenite $\left(\mathrm{FeTiO}_{3}\right)$ mixed with cassiterite. Metal prills in this slag have $7-11 \% \mathrm{Sn}$ and up to $2 \% \mathrm{Fe}$. The titanium enrichment leads us to suggest cassiterite cementation even though no $\mathrm{SnO}_{2}$ crystals were found in this particular slag layer.

There is one crucible that deserves individual discussion, as its functional assignation was initially less clear-cut. Crucible 429 (Fig. 10) still preserves a relatively large copper prill, ca. $500 \mu \mathrm{m}$ in diameter, adhering to the inner surface (Fig. 10A and B). The top side of this prill shows clear evidence of it being oxidised, with the copper turning into

Table 1

Average chemical composition by SEM-EDS of ceramic matrices of crucibles. Results in weight percent, normalized to 100 and with oxygen added by stoichiometry.

\begin{tabular}{|c|c|c|c|c|c|c|c|c|c|c|c|c|}
\hline & $\mathrm{Na}_{2} \mathrm{O}$ & $\mathrm{MgO}$ & $\mathrm{Al}_{2} \mathrm{O}_{3}$ & $\mathrm{SiO}_{2}$ & $\mathrm{P}_{2} \mathrm{O}_{5}$ & $\mathrm{~K}_{2} \mathrm{O}$ & $\mathrm{CaO}$ & $\mathrm{TiO}_{2}$ & $\mathrm{MnO}$ & $\mathrm{FeO}$ & $\mathrm{CuO}$ & $\mathrm{SnO}_{2}$ \\
\hline 405 & 0.2 & 1.1 & 16.5 & 75.5 & 0.3 & 3.4 & 1.0 & 0.1 & bdl & 1.7 & bdl & bdl \\
\hline 407 & 0.2 & 1.2 & 16.6 & 75.8 & 0.3 & 3.5 & 1.0 & 0.1 & bdl & 1.2 & bdl & bdl \\
\hline 417 & 0.3 & 1.1 & 15.0 & 75.9 & 0.3 & 3.5 & 2.0 & 0.1 & bdl & 1.2 & 0.1 & 0.5 \\
\hline 421 & 0.2 & 1.0 & 14.1 & 79.3 & 0.3 & 3.2 & 0.9 & 0.0 & bdl & 1.0 & 0.1 & bdl \\
\hline 424 & 0.1 & 0.9 & 19.5 & 68.6 & 0.5 & 4.7 & 0.6 & 0.9 & bdl & 3.1 & 0.7 & 0.3 \\
\hline 429 & 0.7 & 1.1 & 16.8 & 74.3 & 0.2 & 4.4 & 0.8 & 0.1 & bdl & 1.0 & 0.5 & 0.1 \\
\hline 420 & 0.2 & 0.8 & 15.9 & 72.7 & 0.5 & 2.8 & 0.3 & 0.6 & bdl & 6.0 & 0.2 & bdl \\
\hline 781 & 0.1 & 1.0 & 15.1 & 74.0 & 0.2 & 2.7 & 0.1 & 0.7 & 0.1 & 5.6 & 0.1 & 0.1 \\
\hline Mean 'white' & 0.3 & 1.1 & 16.4 & 74.9 & 0.3 & 3.8 & 1.0 & 0.2 & bdl & 1.5 & 0.3 & 0.3 \\
\hline Mean ‘dark' & 0.1 & 0.9 & 15.5 & 73.4 & 0.4 & 2.7 & 0.2 & 0.7 & $<0.1$ & 5.8 & 0.2 & 0.1 \\
\hline
\end{tabular}


Table 2

Average chemical composition by SEM-EDS of crucible slags. Results in weight percent, normalized to 100 and with oxygen added by stoichiometry.

\begin{tabular}{|c|c|c|c|c|c|c|c|c|c|c|c|c|c|c|c|c|c|c|}
\hline & $\mathrm{Na}_{2} \mathrm{O}$ & $\mathrm{MgO}$ & $\mathrm{Al}_{2} \mathrm{O}_{3}$ & $\mathrm{SiO}_{2}$ & $\mathrm{P}_{2} \mathrm{O}_{5}$ & $\mathrm{SO}_{3}$ & $\mathrm{Cl}$ & $\mathrm{K}_{2} \mathrm{O}$ & $\mathrm{CaO}$ & $\mathrm{TiO}_{2}$ & $\mathrm{MnO}$ & $\mathrm{FeO}$ & $\mathrm{CoO}$ & $\mathrm{CuO}$ & $\mathrm{ZnO}$ & $\mathrm{As}_{2} \mathrm{O}_{3}$ & $\mathrm{SnO}_{2}$ & $\mathrm{PbO}$ \\
\hline 405 & 0.6 & 2.5 & 10.4 & 48.4 & 1.2 & 0.1 & bdl & 3.8 & 4.5 & 0.1 & 6.0 & 9.3 & $<0.1$ & 4.3 & bdl & bdl & 7.6 & 1.2 \\
\hline 407 & bdl & bdl & 1.2 & 4.7 & bdl & bdl & 0.2 & bdl & bdl & bdl & 0.5 & 4.5 & bdl & 61.3 & bdl & 0.2 & 25.3 & 2.0 \\
\hline 417 & 0.6 & 3.5 & 13.8 & 52.8 & 2.7 & bdl & bdl & 5.1 & 9.8 & 0.3 & 0.4 & 4.2 & bdl & 1.5 & bdl & 0.1 & 4.7 & 0.6 \\
\hline 420 & bdl & 1.4 & 8.7 & 35.6 & 0.7 & bdl & bdl & 2.4 & 2.1 & 0.2 & 1.7 & 5.2 & bdl & 23.3 & bdl & bdl & 16.9 & 1.7 \\
\hline 421 & 0.3 & 1.1 & 13.2 & 69.8 & 0.7 & bdl & bdl & 4.5 & 2.6 & 0.6 & 0.1 & 6.7 & bdl & 0.2 & bdl & bdl & bdl & bdl \\
\hline 424 & bdl & 1.5 & 11.5 & 47.5 & 1.8 & bdl & bdl & 6.5 & 7.3 & 0.3 & 3.1 & 12.8 & bdl & 6.1 & bdl & bdl & 0.8 & 0.7 \\
\hline 429 & 0.5 & 2.1 & 9.5 & 43.6 & 2.2 & bdl & bdl & 4.0 & 7.6 & bdl & 0.4 & 8.7 & bdl & 14.4 & bdl & bdl & 1.2 & 5.8 \\
\hline 730 & bdl & 1.5 & 3.3 & 18.7 & 1.4 & $<0.1$ & bdl & 1.8 & 4.8 & bdl & 0.3 & 38.4 & bdl & 4.7 & bdl & bdl & 24.7 & 0.5 \\
\hline 801 & bdl & 0.1 & 4.5 & 24.7 & 0.2 & 1.1 & 0.0 & 0.5 & 1.2 & 0.2 & 0.4 & 61.8 & bdl & 4.7 & 0.6 & bdl & bdl & bdl \\
\hline
\end{tabular}

an oxide. This area is also very rich in rhomboidal cassiterite crystals - a diagnostic morphology that is well-known to derive from the oxidation of metallic tin (Dungworth, 2000b; Rovira, 2007). Interspersed among these are thin needles rich in iron and copper oxide, which were hard to analyse by SEM-EDS due to their small size, but whose morphology is consistent with delafossite $\left(\mathrm{CuFeO}_{2}\right)$ (Fig. $10 \mathrm{D}$ and $\mathrm{E}$ ). In the areas rich in tin oxide, some globules of cuprite are present too. On first impression, this assemblage could seem to result from the high-temperature oxidation of iron-rich bronze: a bronze prill would have lost all of its tin and iron through oxidation, leading to the formation of the crystals described. Here, however, the diagnostic trait appears in the SEMEDS analyses of the $\mathrm{SnO}_{2}$ crystals, which systematically show around $0.5 \% \mathrm{Ta}_{2} \mathrm{O}_{5}$. As the columbite-tantalite series $\left[(\mathrm{Fe}, \mathrm{Mn})(\mathrm{Nb}, \mathrm{Ta})_{2} \mathrm{O}_{6}\right]$ is a family of minerals often occurring as minor accessory minerals with cassiterite, this would seem the most parsimonious explanation for the presence of tantalum oxide in the tin oxide crystals. Even if their shape is indicative of neoformation subsequent to melting, their chemistry retains the tantalum impurity and hence denotes that, also in this case, cassiterite entered the crucible as a mineral.

\subsection{Bronze melting}

Of the eight crucible samples analysed, only one lacked diagnostic evidence that would indicate a former utilisation for bronze making, as opposed to simple remelting of metal stock. We acknowledge, however, that the absence of evidence is not conclusive, as the successful cementation of pure cassiterite with metallic copper in reducing conditions could equally have led to this undiagnostic residue. Crucible 407 (Fig. 11A) bears a dross layer that is affected by post-depositional corrosion, resulting in distorted microstructures and local enrichment in $\mathrm{Cl}$ and $\mathrm{S}$, but it is still possible to recognise numerous euhedral cassiterite crystals in a mass of copper oxides, consistent with the high-temperature oxidation of metallic bronze (Fig. 11B).

Table 3

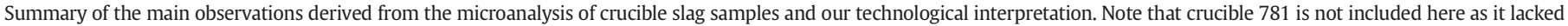
residues of use ( $\mathrm{x}=$ presence; $\mathrm{xxx}=$ abundance $)$.

\begin{tabular}{|c|c|c|c|c|c|c|c|c|c|}
\hline & $\begin{array}{l}405 \\
\text { Crucible }\end{array}$ & $\begin{array}{l}407 \\
\text { Crucible }\end{array}$ & $\begin{array}{l}417 \\
\text { Crucible }\end{array}$ & $\begin{array}{l}421 \\
\text { Crucible }\end{array}$ & $\begin{array}{l}420 \\
\text { Crucible }\end{array}$ & $\begin{array}{l}424 \\
\text { Crucible }\end{array}$ & $\begin{array}{l}429 \\
\text { Crucible }\end{array}$ & $\begin{array}{l}730 \\
\text { Slag }\end{array}$ & $\begin{array}{l}801 \\
\text { Slag }\end{array}$ \\
\hline \multicolumn{10}{|l|}{ Metal prills } \\
\hline Sn\% & 3 to 15 & Corroded & 6 to 26 & 7 to 11 & & 0 to 30 & & 6 to 56 & 2 \\
\hline $\mathrm{Fe} \%$ & & & & 2 & 0.5 & 2 & & 3 & 7 \\
\hline Other & $\mathrm{As}, \mathrm{Sb}, \mathrm{Pb}$ & $\mathrm{Pb}$ & As & $\mathrm{Ni}, \mathrm{As}$ & & $\mathrm{Ni}, \mathrm{As}, \mathrm{Ag}, \mathrm{Sb}, \mathrm{Pb}$ & $\mathrm{As}, \mathrm{Sb}, \mathrm{Pb}$ & As, $\mathrm{Pb}$ & $\mathrm{S}, \mathrm{Zn}$ \\
\hline \multicolumn{10}{|l|}{ Slag enrichment } \\
\hline $\mathrm{Ca}+\mathrm{Mg}$ & $\mathrm{xxx}$ & & $\mathrm{xxx}$ & & $x x x$ & $\mathrm{x}$ & $x x x$ & $\mathrm{xxx}$ & $\mathrm{xxx}$ \\
\hline Mn & $\mathrm{xxx}$ & & $\mathrm{x}$ & & $\mathrm{x}$ & $\mathrm{xxx}$ & & $\mathrm{x}$ & $\mathrm{x}$ \\
\hline $\mathrm{Fe}$ & $\mathrm{xxx}$ & $\mathrm{x}$ & $\mathrm{x}$ & $\mathrm{x}$ & $\mathrm{xxx}$ & $\mathrm{xxx}$ & $\mathrm{x}$ & $\mathrm{xxx}$ & $\mathrm{xxx}$ \\
\hline $\mathrm{Ti}$ & & & & $\mathrm{xxx}$ & & $\mathrm{x}$ & & $\mathrm{x}$ & \\
\hline Other & & $\mathrm{S}, \mathrm{Cl}$ & & & & & & & $\mathrm{S}, \mathrm{Ba}, \mathrm{CuS}$ \\
\hline \multicolumn{10}{|l|}{ Iron crystals } \\
\hline Metallic & & & & $\mathrm{x}$ & & & & & \\
\hline Wüstite & & & & & & $\mathrm{x}$ & & $\mathrm{x}$ & $\mathrm{xxx}$ \\
\hline Delafossite & & & & & $\mathrm{xxx}$ & $\mathrm{x}$ & $\mathrm{xxx}$ & & \\
\hline Spinel & & & & & $\mathrm{xxx}$ & $\mathrm{xxx}$ & & $\mathrm{xxx}$ & $\mathrm{xxx}$ \\
\hline Olivine & & & & & & $\mathrm{x}$ & & & $\mathrm{xxx}$ \\
\hline \multicolumn{10}{|l|}{ Tin oxide crystals } \\
\hline Rhomboidal & $\mathrm{x}$ & $\mathrm{xxx}$ & $\mathrm{x}$ & & $\mathrm{x}$ & & $\operatorname{xxx}(\mathrm{Ta})$ & $\mathrm{xxx}$ & \\
\hline Acicular & $\mathrm{x}$ & & $\mathrm{x}$ & & $\mathrm{x}$ & & $\mathrm{xxx}$ & $\mathrm{xxx}$ & \\
\hline Anhedral/nodular & $\mathrm{xxx}$ & & $\mathrm{x}$ & & $\mathrm{xxx}$ & $\mathrm{x}$ & & $\mathrm{xxx}$ & \\
\hline Pseudomorphs & $\mathrm{xxx}$ & & $\mathrm{x}$ & & $\mathrm{xxx}$ & & & $\mathrm{xxx}$ & \\
\hline \multicolumn{10}{|c|}{ Copper oxide crystals } \\
\hline Globular & $\mathrm{x}$ & & & & $\mathrm{xxx}$ & $\mathrm{x}$ & $\mathrm{x}$ & $\mathrm{x}$ & \\
\hline Anhedral & & & & & $\mathrm{xxx}$ & $\mathrm{x}$ & & & \\
\hline Cubic & $\mathrm{x}$ & & & & & & $\mathrm{x}$ & & \\
\hline Dendritic & & & & & $\mathrm{x}$ & & $\mathrm{x}$ & & \\
\hline \multicolumn{10}{|l|}{ Interpretation } \\
\hline Cementation & $\mathrm{x}$ & & $\mathrm{x}$ & $\mathrm{x}$ & & $\mathrm{x}$ & $\mathrm{x}$ & $\mathrm{x}$ & \\
\hline Co-smelting & & & & & $\mathrm{x}$ & $?$ & & & \\
\hline Bronze melting & & $\mathrm{x}$ & & & & & & & \\
\hline Copper smelting & & & & & & & & & $\mathrm{x}$ \\
\hline
\end{tabular}


A

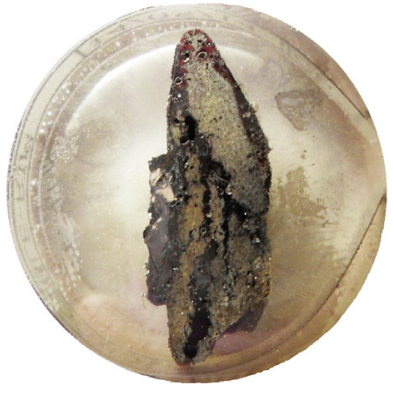

$1 \mathrm{~cm}$
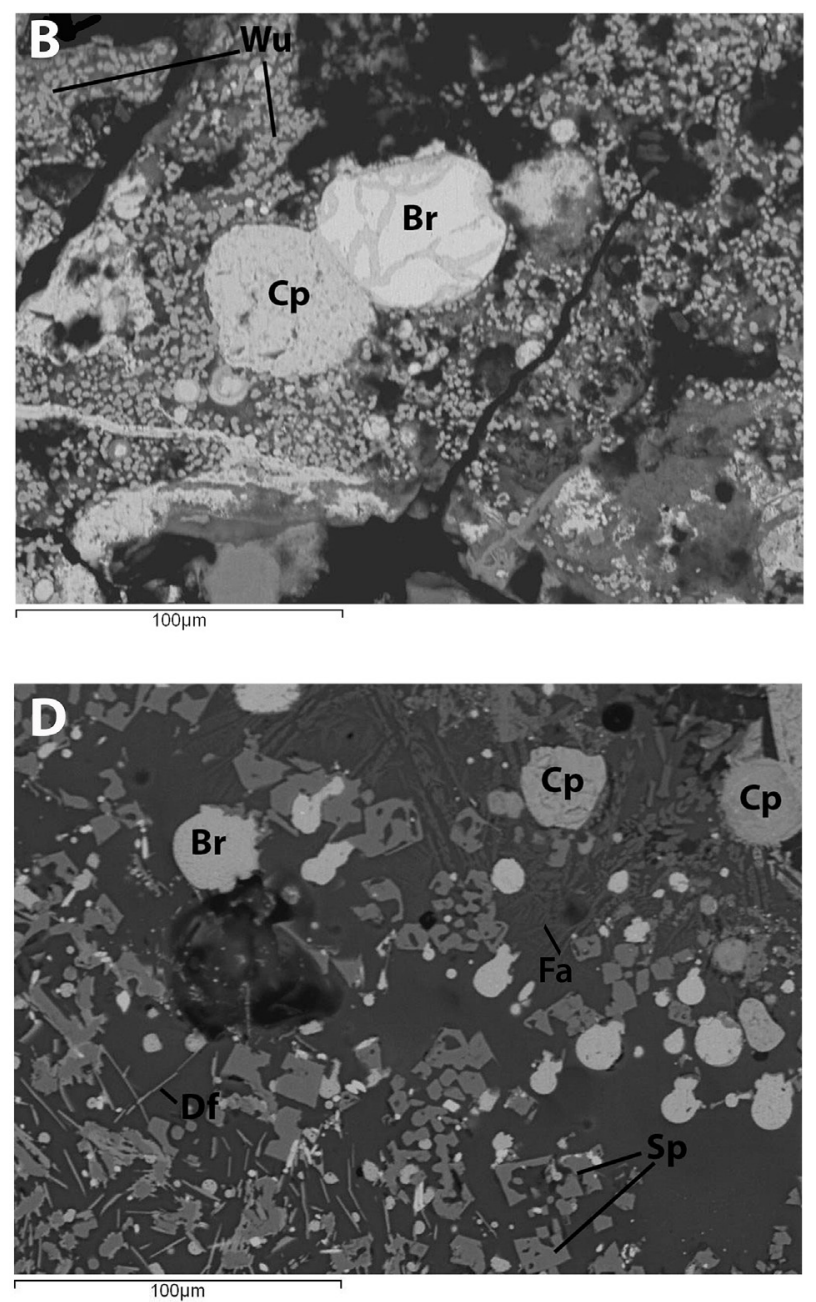

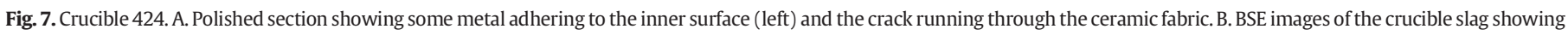

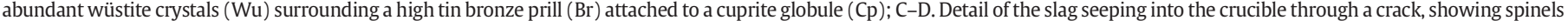
(Sp) oxidising out of copper metal prills (Cu); D) fayalite crystals (Fa), delafossite needles (Df) bronze prills, cuprite nodules (Cp) and spinels (Sp).

\subsection{Smelting?}

We mentioned above the difficulties in recognising conclusively the intentional addition of copper mineral to the crucible charge for the production of bronze by co-smelting. As such, it is possible that some of the samples discussed previously derive from co-smelting rather than cementation. In one case, however, the evidence points most clearly towards the co-smelting of copper and tin minerals. The silicate slag layer in crucible 420 (Fig. 12) is dominated by copper and tin oxides, but it also shows a very significant enrichment in iron and, to lesser extents, manganese, calcium and magnesium oxides (see Table 2). A relatively large metal bleb was found to be iron-bearing copper, surrounded by a thin iron- and tin-rich envelope. Most significant is the presence of angular clusters of crystals dispersed within the slag. While their relative proportions vary, these are made of variable combinations of nodular cuprite, acicular delafossite and predominantly nodular cassiterite (Figs. 12B-D).The co-occurrence of the three oxide crystals in clusters might be taken as an indication that they formed by oxidation of ironrich bronze. However, the angular shape of these clusters, and the morphology of the copper and tin crystals, argue against this.

We are inclined to interpret this evidence as indicative of an attempt to co-smelt copper and tin minerals that were finely ground and mixed together. It is worth mentioning the work by Rovira and Gómez Ramos (2001) at the nearby hillfort of La Campa Torres: here, researchers documented several examples of nodules of partly fused minerals, invariably rich in both tin and copper, which they interpreted as intermediate products of co-smelting, perhaps resulting from incomplete reactions or pre-formed mixtures meant to be used at a later stage. If such conglomerates where crushed and fed into a crucible, they could conceivably lead to slag microstructures such as that described above.

The last sample to be discussed is a small $($ c. $1 \mathrm{~cm})$ nodule of slag (801; Fig. 13). Internally heterogeneous, and with limited fluidity, it could well have formed inside a crucible. The slag is predominantly dominated by olivines (with minor amounts of $\mathrm{Zn}, \mathrm{Mn}, \mathrm{Mg}$ and Ca; see Table 2), but it contains some areas very rich in wüstite, as well as others dominated by alumina- and titanium-bearing iron spinels (Fig. $13 \mathrm{~A}$ ). Within the slag there are numerous globules of metallic copper containing up to $7 \%$ iron and $2 \%$ tin, and occasional traces of sulphur (Fig. 13B). There are also larger grains of residual, largely unreacted covellite $(\mathrm{CuS})$, sometimes associated to barite $\left(\mathrm{BaSO}_{4}\right)$ (Fig. $\left.13 \mathrm{C}\right)$. We interpret this slag as indicative of copper mineral smelting. Clearly, the charge was rich in iron and included sulphidic copper minerals, although these were not necessarily predominant. Although small amounts of tin are present in the metal, it is impossible to tell whether this metal would have been an impurity in the ore, a deliberate addition or perhaps just remainders of contamination in the crucible from previous usage with bronze.

\section{Discussion}

The analytical results presented and discussed above illustrate some of the challenges associated to attempts at identifying metallurgical 

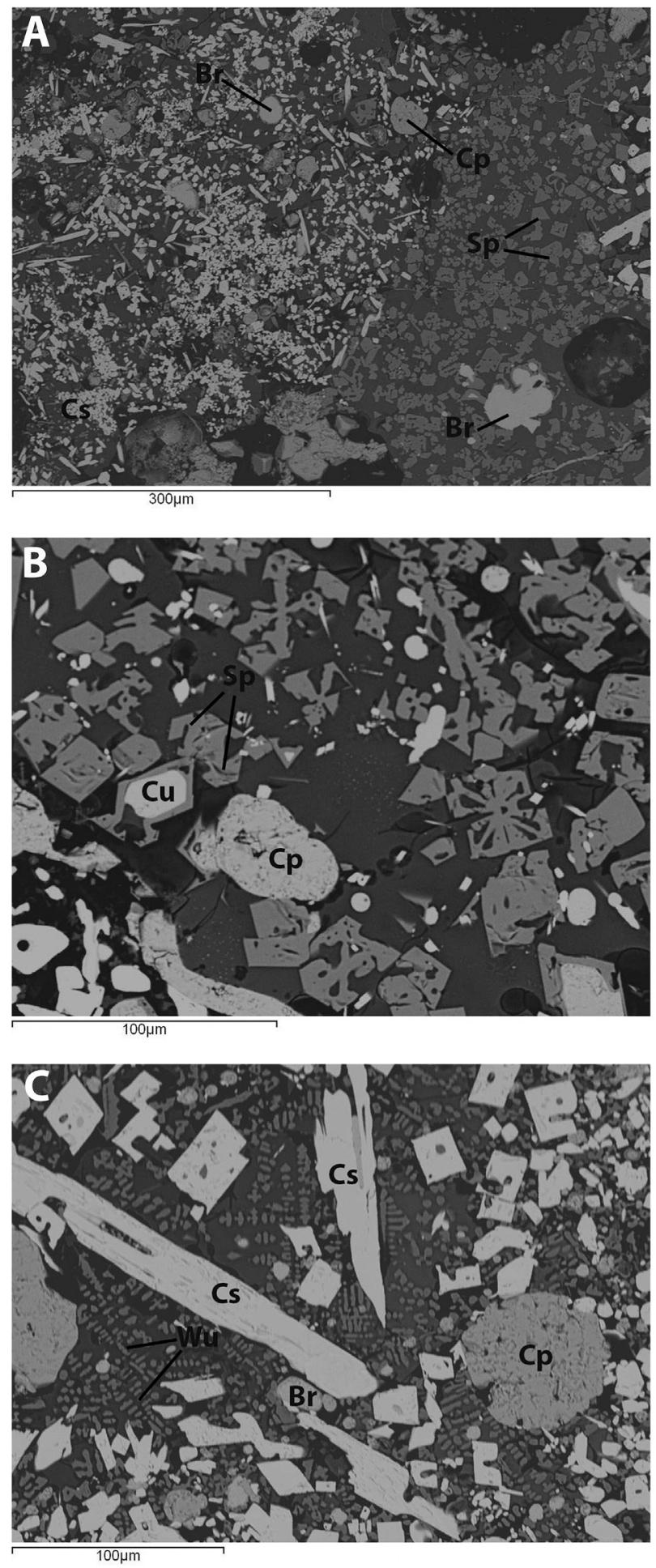

Fig. 8. Slag nodule 730. BSE images showing: A. a spinel-rich area (Sp) next to another area where cuprite globules $(\mathrm{Cp})$ occur together with high tin bronze prills $(\mathrm{Br})$ and numerous cassiterite crystals of various shapes (Cs); B. Detail of copper metal $(\mathrm{Cu})$, spinels $(\mathrm{Sp})$ and cuprite globule; $\mathrm{C}$. Detail of bronze (Br), cuprite (Cp) and cassiterite (Cs) crystals in a slag matrix rich in wüstite crystals $(\mathrm{Wu})$.

processes through the analyses of crucible residues. Some features of the crucible slags can be quite diagnostic: for example, the presence of pseudomorphs of nodular cassiterite provides incontestable evidence that tin-bearing minerals were added to the charge (e.g. samples 405 , $417,424,730$ ) (see also Rademakers et al., 2013). However, as ever, their absence does not preclude their former presence - they may

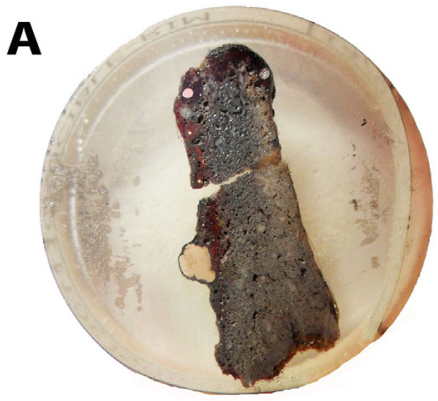

$1 \mathrm{~cm}$

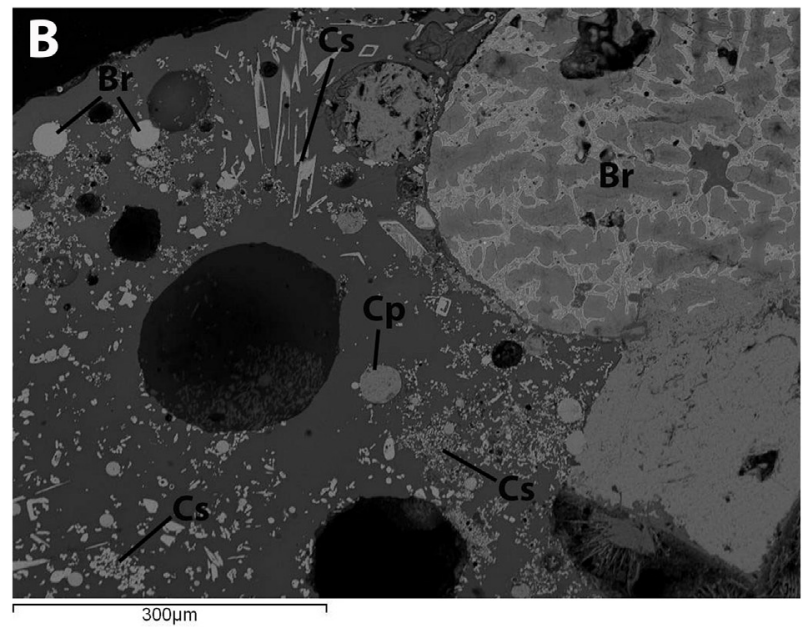

Fig. 9. A. Crucible 405. A. Polished section showing numerous metallic prills and red copper corrosion products; B. BSE image of a large cubic grain of cuprite formed inside a pore (bottom right). The micrograph also shows the presence of a bigger bronze prill $(\mathrm{Br})$ along with smaller ones, cuprite globules $(\mathrm{Cp})$ and cassiterite crystals of various shapes (Cs). (For interpretation of the references to colour in this figure legend, the reader is referred to the web version of this article.)

simply have been reduced to metal and hence disappeared. Similarly, while newly formed, euhedral tin oxide grains are generally known to derive from 'burnt bronze' rather than being indicative of mineral additions to the charge (e.g. Dungworth, 2000b; Rovira, 2007), we showed above a case of misleadingly neoformed crystals that however preserved the tantalum signature of the tin ore (sample 429). In this sense, where detected, $\mathrm{Nb}$ and Ta may be the best proxies for the former presence of cassiterite mineral in the charge, given their rarity in other mineral formations. Other oxides such as titanium (in ilmenite) and iron (in magnetite) are common gangue associated to cassiterite, but they may also be associated to copper ores or, in the case of iron, to ferruginous copper metal. Finally, although residual copper minerals can be preserved in the slag and identified with confidence (sample 801), we raised caution against the interpretation of any copper compound crystals as indicative of copper minerals in the charge - with some cases of cuprite seemingly formed after the reaction had ended (samples 405,429 ). The analytical characterisation is further complicated by the variability of structures expected at different sampling points of the crucible (Rademakers and Rehren, 2016) as well as by the fact that crucibles could well have been used for more than one reaction, resulting in mixed signatures. Clearly, more experiments are needed under controlled conditions to establish the diagnostic features to be expected in each case (cf. Rovira et al., 2009; Dungworth, 2000b; Rademakers and Farci, in preparation).

These challenges notwithstanding, the evidence presented is sufficient to contend that nonferrous metalworking at El Castru in Vigaña 


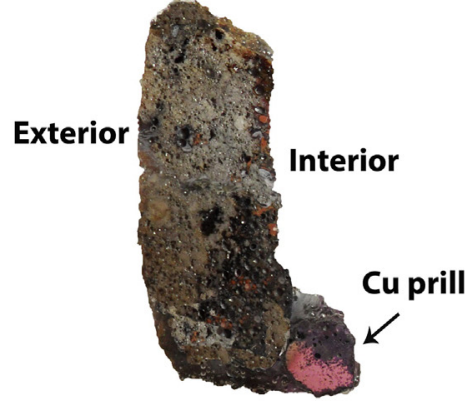

A
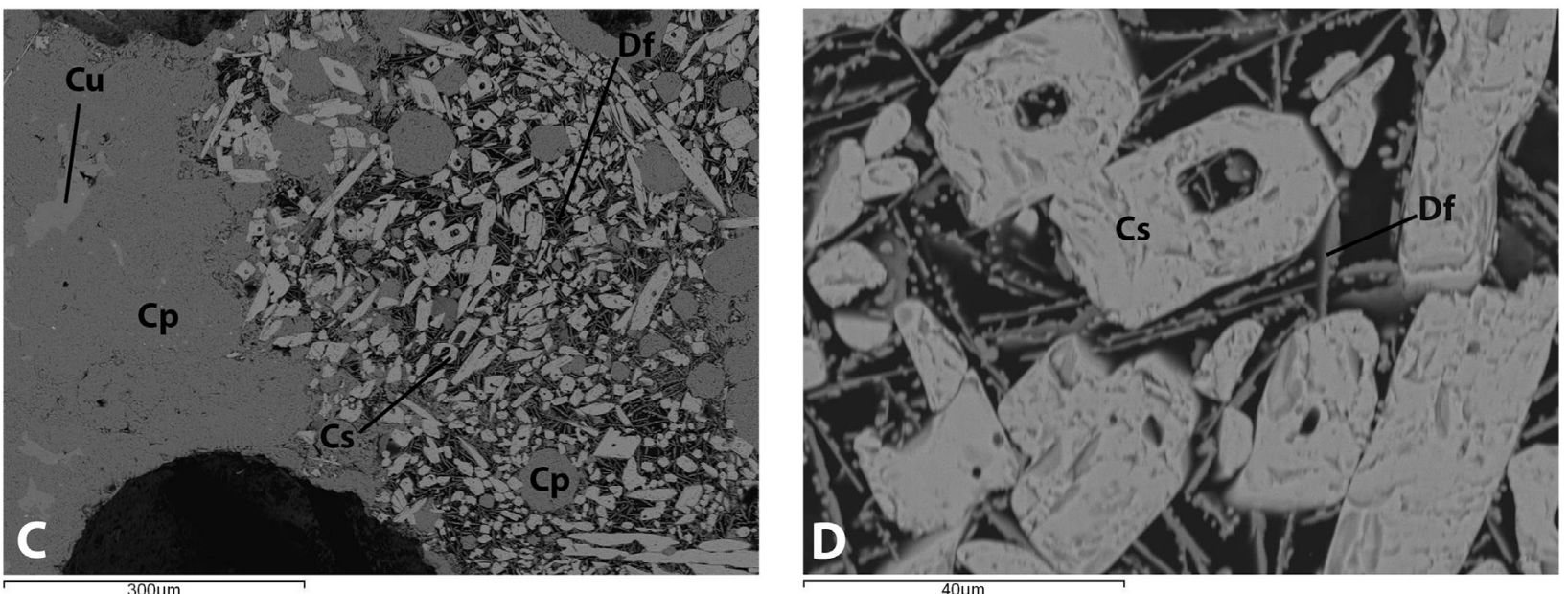

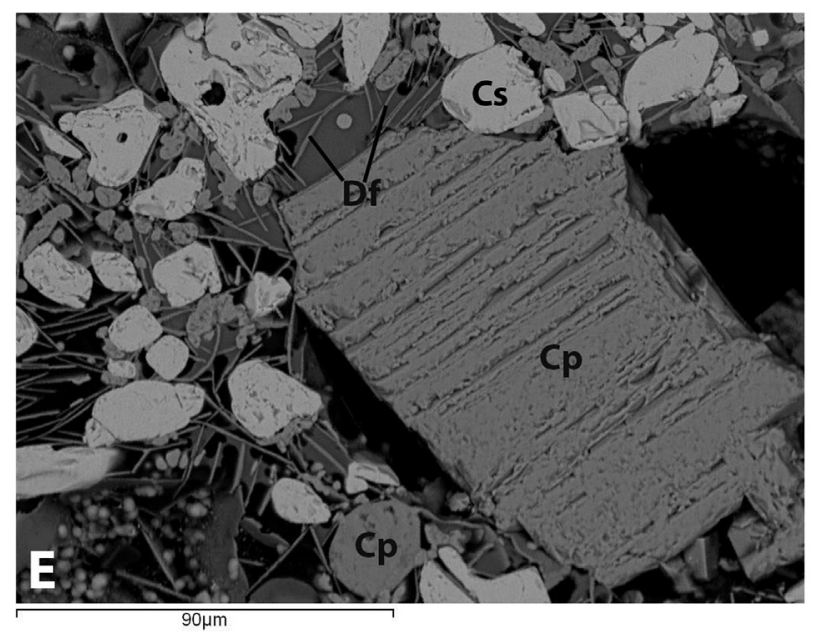

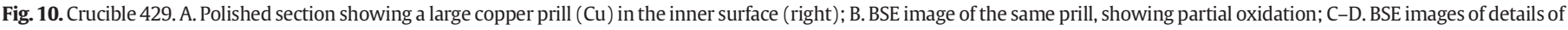

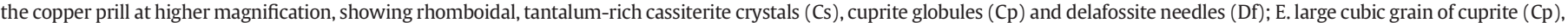
clearly formed inside a pore.

most probably involved the cementation of cassiterite with metallic copper in small, internally heated crucibles, and that copper smelting and co-smelting of copper and tin are likely to have taken place too (see Table 3 for a summary of results and interpretations). Although harder to identify positively (not least because of our sampling biased towards more slagged sherds), it seems reasonable that melting of scrap bronze or small ingots took place too, probably in the same crucibles and even in combination with mineral charges (for example, 'strengthening' weakly alloyed bronze scrap through cementation with cassiterite). While lead is detected occasionally in the debris, we cannot confirm whether this would have been added deliberately to the charge (either as a mineral or as a metal), or inadvertently as an 


\section{A}

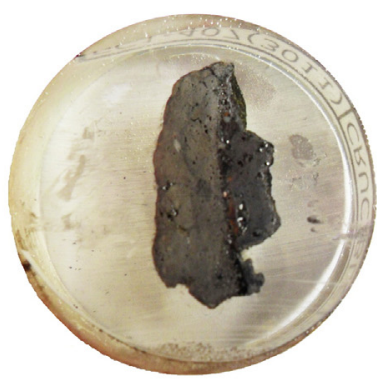

$\overline{1 \mathrm{~cm}}$

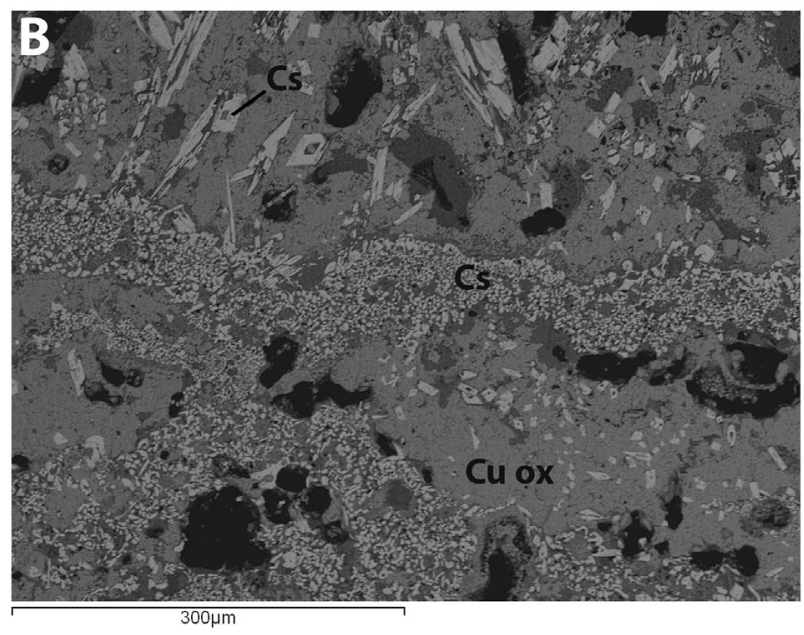

Fig. 11. A. Crucible 407. A. Polished section showing a relatively thick residue on the inner surface (right); B. BSE image showing a dross layer, whose structure is consistent with the high-temperature oxidation of metallic bronze, namely euhedral cassiterite crystals (Cs) dispersed in a mass of copper oxides ( $\mathrm{Cu}$ ox).

impurity with the copper. In any case, lead is unlikely to have formed a major alloying constituent, as suggested by the generally low levels in the slag and metal prills, and corroborated by our analysis of two samples of casting spillage with $11 \%$ tin and $2 \%$ lead (samples 796,798 ; also see Rovira and Gómez Ramos, 2001 for similar compositions in bronzes from La Campa Torres). These operations took place in a small workshop within the settlement, probably catering for the needs of the small community at the hillfort of El Castru only. Future archaeometallurgical research should investigate in more detail the differences that may have existed in both the technology and context of metallurgical activities in NW Iberia during the Late Iron Age, hence enhancing our understanding of the internal regional diversity (González Ruibal, 2006, 2011), following the examples of previous work on pottery production and consumption (Marín Suárez, 2012), or for the domestic space organisation (Ayán Vila, 2013). For now, our picture is inevitably simplistic and generalising.

Although detailed studies of bronze making in the Iron Age of the Iberian Peninsula are scarce, when these are brought to the picture the case of the hillfort of El Castru in Vigaña does not seem exceptional. Still, it is worth highlighting the broader significance of this pattern. Of particular relevance here is the case of La Campa Torres mentioned above. Metallurgical remains at this site are much more abundant but they also point to the co-smelting of copper and tin minerals in relatively small crucibles (although, notably, with different gangue oxides recorded) (Rovira and Gómez Ramos, 2001). At the hillfort of Llagú, technical ceramics have not undergone analytical study, but some are morphologically very similar to those analysed here (Berrocal-Rangel et al., 2002). Further work will be necessary to investigate possible connections among these sites (e.g. whether crucibles were made by specialists or manufactured locally but to shared shape and design). However, the evidence available points to relatively small scale settlement-based metallurgical workshops, where crucible smelting, cosmelting and remelting were carried out following a millennia-long tradition.

The use of crucibles rather than furnaces for the production of copper and copper alloys in low intensity, settlement-based production settings seems the norm rather than the exception in Iberia from the Chalcolithic right through to the Iron Age (Maya González et al., 1993, Gómez Ramos, 1999, Diaz et al., 2001, Rovira, 2007, Figueiredo et al., 2010, Valério et al., 2013); especially at sites far from the Mediterranean influence, smelting crucibles were in use up to Roman times (Fernández-Posse et al., 1993, Rovira and Montero-Ruiz, 2013: 234). There is a rather convincing explanation for this technological tradition. As argued by others before us (e.g. Maya González et al., 1993; Rovira, 2002; Hunt Ortiz, 2003) the relatively widespread availability of copper and tin minerals in parts of Iberia meant that there was little pressure for metallurgists to specialise, seek more cost-effective techniques, or engage in long distance trade to ensure the supply of metals. This availability also precluded attempts to centralise production control. The result was a relatively conservative metallurgy that changed very little in spite of the significant social transformations taking place since the Chalcolithic. Of course, Iberia was not isolated, and the impact of contact across the Atlantic façade and Phoenician influences can be recognised in other dimensions of metallurgy (Sastre, 2011; González García et al., 2011; Renzi and Rovira, 2015). In this sense, understanding the role of iron and the impact that the new metal had on social and technological aspects of Late Iron Age settlements will certainly offer a better and possibly more complex picture of the production systems. However, the emphasis on cultural contact and change should not lead us to forget about the eminently stagnant nature of the metallurgical practice documented here. Needless to say, this is not a value judgement but simply a reflection of how technology was adapted to this peculiar environmental and social context.

While seemingly not as frequently as in Iberia, crucible-based bronze-making by cementation and co-smelting has also been reported in other regions. For example, it has been demonstrated that bronze making by cassiterite cementation took place routinely in the Late Bronze Age Egyptian capital of Qantir, at large, centrally-administered workshops (Rademakers et al., 2013; Rademakers, 2015) and similar practices have been documented elsewhere (Rostoker et al., 1983, Papadimitrou et al., 1992, Murillo-Barroso et al., 2010, Eliyahu-Behar et al., 2012). The identification of this practice in the Egyptian case might seem particularly surprising, as this was taking place in a world of large scale, furnace-based specialised copper and tin smelters, integrated in networks of long distance trade of oxhide ingots - as evidenced for instance in the metal cargo aboard the Uluburun ship (Pulak, 2000). The co-existence of several bronze production methods at the same site reminds us that technological alternatives were not necessarily in competition with each other, and that generalising models of production and trade should allow for internal diversity, even within the same production contexts.

Returning to Vigaña, this case study also illustrates that smelting and melting were not always and necessarily conceived of as radically different things. Received wisdom is that smelting, as a chemical reaction, is a more complex pyrotechnology often leading to craft specialisation and typically located near the raw materials, whereas melting, alloying, recycling and artefact casting are physical reactions involving significantly different skills and generally taking place near consumers. While there is some truth to this assertion, the assemblage from El Castru suggests that smelting and melting/alloying most likely took place in the same workshop, with the very same tools and raw materials, and probably without much awareness of, or regard to, the fundamental differences between the two. As such, this is yet another case that reminds us of the risks of pushing present-day categorisations in our explanations of past practice. 
A

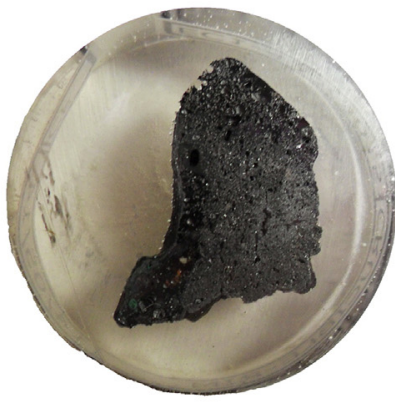

$1 \mathrm{~cm}$
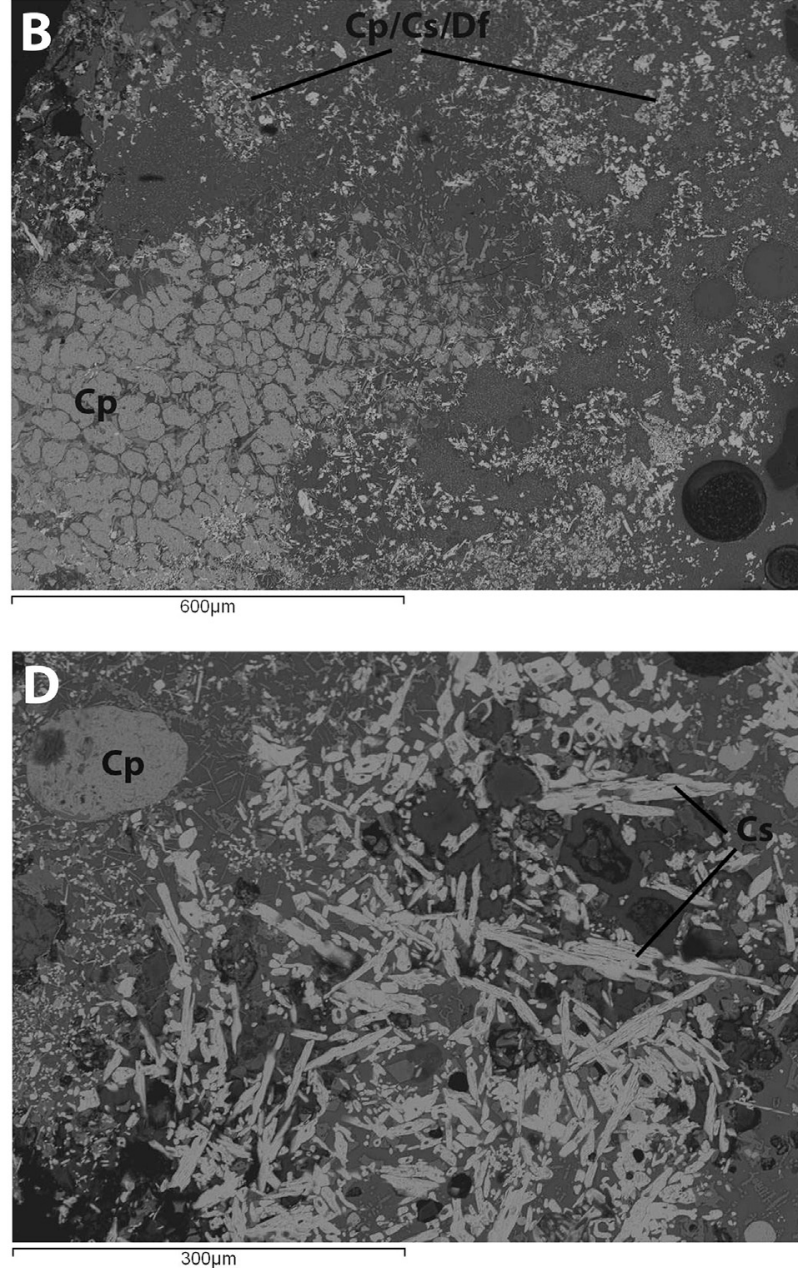

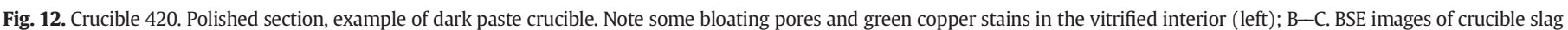

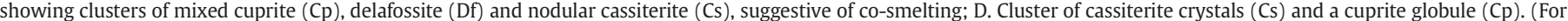
interpretation of the references to colour in this figure legend, the reader is referred to the web version of this article.)

A related issue that should be investigated further is that of the functional differentiation between the so-called 'crucible-furnaces' and the 'melting crucibles' often recorded in Spanish sites. As noted above, we could not identify such types in El Castru, but it is notable that we found no correlation between crucible shape or fabric, and types of metallurgical residue in our admittedly small sample. At La Campa Torres, Rovira and Gómez Ramos (2001) acknowledge no fundamental difference in the residues attached to either type of ceramic vessel. Therefore, the applicability of this functional classification, while valid at some sites, should be questioned rather than assumed (Berrocal-Rangel et al., 2002).

Finally, as we add more case studies to the picture, it will be interesting to see the geographic spread of this bronze making tradition as well as its projection in time. For example, we do not know whether bronze makers in the East andSouthwest of Iberia, where tin minerals are less abundant, used predominantly cassiterite or metallic tin (or both). If we assume that cementation and co-smelting allowed less control of the resulting alloy composition than co-melting of metals, perhaps a
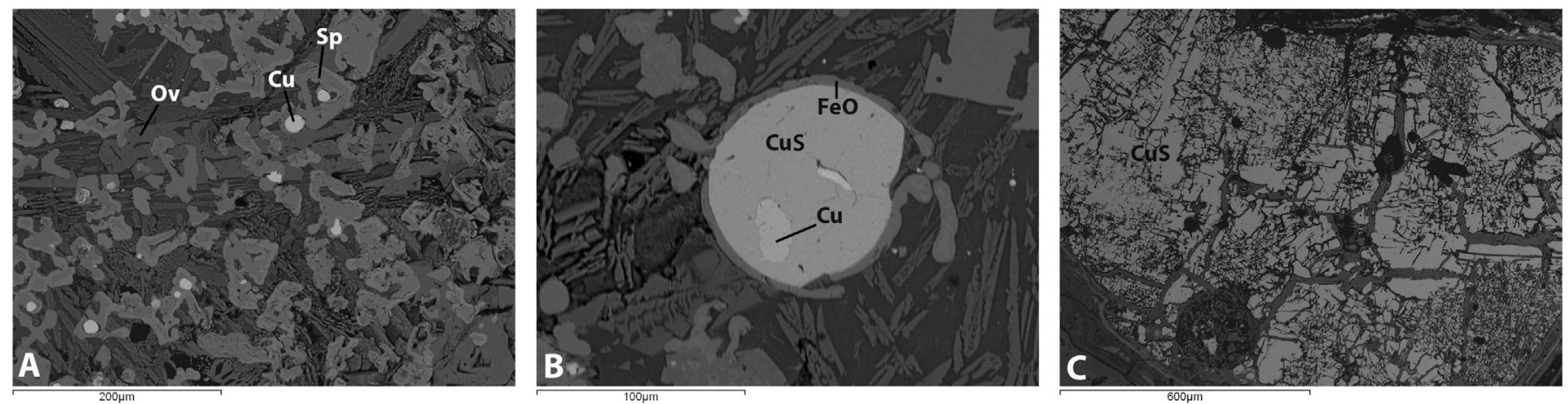

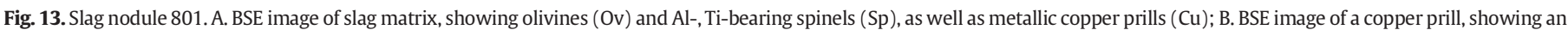
external ring of iron oxide (FeO), some remaining copper metal ( $\mathrm{Cu}$ ) and copper sulphide (CuS); C. BSE image showing a large grain of unreacted covellite (CuS). 
comparative assessment of the standardisation in bronze compositions in different regions might be informative of this matter.

\section{Acknowledgements}

The initial analytical work behind this paper was carried out by the first author for her MSc dissertation at the UCL Institute of Archaeology. She acknowledges with gratitude the financial support from the Region of Sardinia (AF-MU-A2012B-65211-11844/2013), under its "Master and Back" programme. The excavations in El Castru were funded by the project "La formación de los paisajes del Noroeste peninsular durante la Edad Media (Siglos V-XII)" (Ref. HAR2010-21950-C03-03) co-ordinated by Margarita Fernández Mier with a grant from the Spanish Research and Development State Secretary. We are grateful to Harriet White for her invaluable support at the UCL Wolfson Archaeological Science Laboratories, as well as to Xosé-Lois Armada for his expert suggestions.

\section{References}

Ayán Vila, X.M., 2013. Todo queda en casa: Espacio doméstico, poder y división social en la Edad del Hierro del NW de la península ibérica. In: Gutiérrez Lloret, S., Grau Mira, I. (Eds.), De la estructura doméstica al espacio social. Lecturas arqueológicas del uso social del espacio. Publicaciones de la Universidad de Alicante, Alicante, pp. 39-56.

Berrocal-Rangel, L., Martínez Seco, P., Ruiz Triviño, C., 2002. El Castiellu de Llagú (Latores, Oviedo). Un castro astur en los orígenes de Oviedo. Real Academia de la Historia, Madrid, pp. 194-199.

Camino Mayor, J., Villa Valdés, A., 2014. El hierro en registro arqueológico de la protohistoria cantábrica. Kobie SErie Anejo 13, 59-74.

Cooke, S.R.B., Nielsen, B.V., 1978. Slags and other metallurgical products. In: Rapp Jr., G., Arschenbrenner, S.E. (Eds.), Excavations at Nichoria in Southwest GreeceSite, Environs and Techniques Vol. 1. University of Minnesota Press, Minneapolis, pp. 182-224.

Crew, P., Rehren, T., 2002. High-temperature workshop residues from Tara: iron, bronze and glass. Discov. Program. Rep. 6, 83-103.

de Blas Cortina, M.A., Suárez Fernández, M., 2010. La minería subterránea del cobre en Asturias: un capítulo esencial en la Prehistoria reciente del norte de España. In: Fernández-Tresguerres, J. (Ed.), Cobre y Oro. Minería y metalurgia en la Asturias prehistórica y antigua. Real Instituto de Estudios Asturianos, Oviedo, pp. 43-82.

de la Peña Santos, A., 1988. Metalurgia galaica de la transición Bronce-Hierro: el Castro de Torroso. Espacio, Tiempo y Forma, Serie I, Prehistoria, t. I. pp. 339-360.

Diaz, A.R., Soldevila, I.P., Merideth, C., Tresserras, J.J.I., 2001. El Cerro de San Cristobal, Logrosan, Estremadura, Spain. BAR International Series 922. Archaeopress, Oxford.

Dungworth, D., 2000a. A note on the analysis of crucibles and moulds. Hist. Metall. 34, 83-86.

Dungworth, D., 2000b. Serendipity in the foundry? Tin oxide inclusions in copper and copper alloys as an indicator of production process. Bull. Met. Mus. 32, 1-5.

Eliyahu-Behar, A., Yahalom-Mack, N., Shilstein, S., Zukerman, A., Shafer-Elliott, C., Maeir, A.M., Boaretto, E., Finkelstein, I., Weiner, S., 2012. Iron and bronze production in Iron Age IIA Philistia: new evidence from Tell es-Safi/Gath, Israel. J. Archaeol. Sci. 39, 255-267.

Fanjul Peraza, A., Marín Suárez, C., 2006. La Metalurgia del Hierro en la Asturias Castreña: nuevos datos y estado de la cuestión. Trab. Prehist. 63 (1), 113-131.

Fernández Mier, M., González Álvarez, D., 2013. Más allá de la aldea: estudio diacrónico del paisaje en el entorno de Vigaña (Belmonte de Miranda). Excavaciones Arqueológicas en Asturias 2007-2012. En el centenario del descubrimiento de la caverna de La Peña de Candamo. Consejería de Educación, Cultura y Deporte del Principado de Asturias. Dirección General de Patrimonio Cultural, Oviedo, pp. 353-365

Fernández-Posse, M.D., Montero, I., Sanchez-Palencia, F.J., Rovira, S., 1993. Espacio y Metalurgia en la Cultura Castreña: la Zona Arqueológica de las Medulas. Trab. Prehist. 50, 197-220.

Figueiredo, E., Silva, R.J.C., Senna-Martinez, J.C., Fatima Araujo, M., Bras Fernandes, F.M., Ines Vaz, J.L., 2010. Smelting and recycling evidences fom the Late Bronze Age habitat site of Baioes (Viseu, Portugal). J. Archaeol. Sci. 37, 1623-1634.

Gómez Ramos, P., 1999. Obtención de metales en la Prehistoria de la Península Ibérica. BAR International Series 753. Archaeopress, Oxford.

González Álvarez, D., 2016. Poblamiento y antropización de la montaña occidental cantábrica durante la Prehistoria reciente: una aproximación desde la Arqueología del Paisaje. Department of Prehistory, University Complutense of Madrid, Madrid (Unpublished $\mathrm{PhD}$ dissertation).

González Fernández A., 2002. Intervención arqueológica en A Illa do Medio, Santa Comba (Covas). Santa Comba, un referente arqueológico de la costa ferrolana. Sociedad Cultural Columba, Ferrol, pp. 24-65.

González García, F.J., Parcero-Oubiña, C., Ayán Vila, A., 2011. Iron Age societies against the state: an account of the emergence of the Iron Age in North-western Iberia. In: Moore, T., Armada, X.L. (Eds.), Atlantic Europe in the First Millennium BC: Crossing the Divide. Oxford University Press, Oxford, pp. 285-301.

González Ruibal, A., 2006. House societies vs. kinship-base societies: an archaeological case from Iron Age Europe. J. Anthropol. Archaeol. 25 (1), 144-173.
González Ruibal, A., 2011. The politics of identity: ethnicity and the economy of power in Iron Age northern Iberia. In: Cifani, G., Stoddart, S. (Eds.), Landscape, Ethnicity and Identity in the Archaic Mediterranean Area. Oxbow Books, Oxford, pp. 245-266.

Hunt Ortiz, M.A., 2003. Prehistoric Mining and Metallurgy in South West Iberian Peninsula. BAR International Series 1188 2003. Archaeopress, Oxford, pp. 349-370.

Jordá Pardo, J.F., Marín Suárez, C., García-Guinea, J., 2011. Discovering San Chuis Hillfort (Northern Spain): archaeometry, craft technologies, and social interpretation. In: Moore, T., Armada, X.L. (Eds.), Atlantic Europe in the First Millennium BC. Crossing the Divide. Oxford University Press, Oxford, pp. 488-505.

Kearns, T., Martinón-Torres, M., Rehren, T., 2010. Metal to mould: alloy identification in experimental casting moulds using XRF. Hist. Metall. 44 (1), 48-58.

Maluquer de Motes, J., 1975. La Cultura Castreña de la Edad del Hierro. Actas de las Jornadas de Metodología Aplicada de las Ciencias Históricas, Vol. 1 (Prehistoria e historia antigua). Servicio de Publicaciones de la Universidad de Santiago de Compostela, Santiago de Compostela, pp. 269-284.

Marín Suárez, C., 2011a. La Edad del Hierro en el occidente cantábrico: de la cultura arqueológica al grupo arqueológico. Férvedes 7, 123-132.

Marín Suárez, C., 2011b. De nómadas a castreños. Arqueología del primer milenio antes de la era en el sector centro-occidental cantábrico. Department of Prehistory, University Complutense of Madrid, Madrid (PhD dissertation, available at). http://eprints ucm.es/14435/.

Marín Suárez, C., 2012. La cerámica de la Edad del Hierro en el sector centro-occidental cantábrico. Munibe. Antropologia-Arkeologia 63, 165-198.

Maya González, J.L., 1983. La Cultura Castreña Asturiana: de los orígenes a la romanización. Indigenismo y romanización en el Conventus Asturum. Oviedo, pp. 11-44.

Maya González, J.L., Cuesta Toribio, F., 2001. Excavaciones arqueológicas y estudio de los materiales de La Campa Torres. In: Maya González, J.L., Cuesta Toribio, F. (Eds.), El castro de La Campa Torres. Período prerromano. VTP editorial, Gijón, pp. 11-277.

Maya González, J.L., Rovira, S., Cuesta Toribio, F., 1993. Metalurgia del Bronce en el Poblado de la Campa Torres (Asturias). Pyrenae 24, 151-158.

Murillo-Barroso, M., Pryce, M., Bellina, T.O., Martinón-Torres, M., 2010. Khao Sam Kaeo an archaeometallurgical crossroads for trans-asiatic technological traditions. J. Archaeol. Sci. 37, 1761-1772.

Papadimitrou, G., Tsaimou, C., Vardavoulias, M., 1992. Bronze production during the Hellenistic period in the Rhodes Island. In: Antonacci-Sanpaolo, E. (Ed.) Archaeometallurgia Ricerche e Prospettive, pp. 227-237.

Parcero Oubiña, C., 2003. Looking forward in anger: social and political transformations in the Iron Age of the North-Western Iberian Peninsula. Eur. J. Archaeol. 6 (3), 267-299.

Pigott, V.C., Rogers, H.C., Nash, S.K., 2003. Archaeometallurgical investigations at Malyan: the evidence for tin-bronze in the Kaftari Phase. In: Miller, N.F., Abdi, K. (Eds.), Yek Bud, Yeki Nabud: Essays on the Archaeology of Iran in Honor of William M. Sumner Cotsen Institute of Archaeology at UCLA, Los Angeles, pp. 161-176.

Pulak, C., 2000. The copper and tin ingots from the Late Bronze Age shipwreck at Uluburun. In: Yalchin, U. (Ed.), Der Anschnitt: Zeitschrift für Kunst and Kultur im Bergbau. Bergbau, Der Anschnitt.

Rademakers, F., 2015. Into the Crucible. Methodological Approaches To Reconstructing Crucible Metallurgy, From New Kingdom Egypt to Late Roman Thrace. (Unpublished PhD thesis). UCL, London.

Rademakers, F.W., Rehren, T., 2016. Seeing the forest for the trees: assessing technological variability in ancient metallurgical crucible assemblages. J. Archaeol. Sci. Rep. 7, 588-596.

Rademakers, F.W., Rehren, T., Pusch, E., 2013. Bronze production in Pi-Ramesse: alloying technology and material use. In: Ben-Yosef, E., Goren, Y. (Eds.), Mining for Copper: Essays in Honor of Professor Beno Rothenberg. Institute of Archaeology of Tel Aviv, Tel Aviv (in press).

Renzi, M., Rovira, S., 2015. Las metalurgias fenicias en el Mediterráneo. Minería y metalurgia en el mediterráneo y su periferia oceánica: III Encuentros Internacionales del Mediterráneo: PHICARIA, pp. 113-127.

Renzi, M., Hauptmann, A., Rovira, S., 2007. Phoenician metallurgical production at S-E Spain. Proceedings of the 2nd International Conference "Archaeometallurgy in Europe 2007", Grado-Aquileia [CD-ROM].

Rostoker, W., McNallan, M., Gebhard, E.R., 1983. Melting/smelting of bronze at Isthmia. Hist. Metall. 17 (1), 23-27.

Rovira, S., 2002. Metallurgy and society in Prehistoric Spain. In: Ottaway, B.S., Wager, E.C. (Eds.), Metals and SocietyBAR International Series 1061. Archaeopress, Oxford, pp. 5-20.

Rovira, S., 2006. Metalurgia de crisol: la obtención de cobre en la prehistoria de la Península Ibérica. De Re Metallica 5, 37-44.

Rovira, S., 2007. La producción de bronces en la prehistoria. In: Molera, J., Farjas, J., Roura P., Pradell, T. (Eds.), Avances En Arqueometría. Actas Del VI Congreso Ibérico De Arqueometría 2005. Universidad de Girona, Girona, pp. 21-35.

Rovira, S., Gómez Ramos, P., 2001. La metalurgia prerromana de La Campa Torres (Gijón, Asturias). In: Maya González, J.L., Cuesta Toribio, F. (Eds.), El castro de La Campa Torres. Período prerromano. VTP editorial, Gijón, pp. 375-384.

Rovira, S., Montero-Ruiz, I., 2013. Iberia: technological development of prehistoric Metallurgy. In: Burmeister, S., Hansen, S., Kunst, M., Müller-Scheeßel (Eds.), Metal Matters. Innovative Technologies and Social Change in Prehistory and Antiquity. VML, Verlag Marie Leidorf, Rahden/Westf, pp. 231-239.

Rovira, S., Montero-Ruiz, I., Renzi, M., 2009. Experimental co-smelting to copper-tin alloys. In: Kienlin, T.L., Roberts, B.W. (Eds.), Metals and Societies. Studies in Honour of Barbara S. Ottaway. Universitatsforschungen zur prahistorischen Archaologie. R. Habelt, Bonn, pp. 407-414.

Sastre, I., 2011. Social inequality during the Iron Age: interpretation models. In: Moore, T. Armada, X.L. (Eds.), Atlantic Europe in the First Millennium BC: Crossing the Divide. Oxford University Press, Oxford, pp. 264-284. 
Valério, P., Monge Soares, A.M., Silva, R.J.C., Araújo, M.F., Rebelo, P., Neto, N., Santos, R., Fontes, T., 2013. Bronze production in southwestern Iberian Peninsula: the Late Bronze Age metallurgical workshop from Entre Águas 5 (Portugal). J. Archaeol. Sci. 40, 439-451.

Villa Valdés, A., 2005. Minería y metalurgia del oro en la Asturias romana. In: Puche, O Ayarzagüena, M. (Eds.), Minería y Metalurgia históricas en el Sudoeste europeo.
Sociedad Española para la Defensa del Patrimonio Geológico y Minero; Sociedad Española de Historia de la Arqueología, Madrid, pp. 197-213.

Yin, M., Rehren, T., Zheng, J., 2011. The earliest high-fired glazed ceramics in China: the composition of the proto-porcelain from Zhejiang during the Shang and Zhou periods. J. Archaeol. Sci. 38, 2352-2365. 